\title{
Weathering behaviour and construction suitability of dimension stones from the Drei Gleichen area (Thuringia, Germany)
}

\author{
Heidrun Stück $\cdot$ Siegfried Siegesmund • \\ Jörg Rüdrich
}

Received: 6 January 2011/Accepted: 22 March 2011/Published online: 12 May 2011

(c) The Author(s) 2011. This article is published with open access at Springerlink.com

\begin{abstract}
The construction suitability of a dimension stone depends on its weathering properties along with the petrology and the petrophysical properties. The aim of this study was to evaluate the suitability of the dimension stones from the "Drei Gleichen" area for construction and replacement purposes. In total, six sandstones (Ingersleben, Wachsenburg, Hindfelden, Seeberg, Röhnberg, Gleichenberg; Upper Triassic) as well as two carbonates (Wachsenburg sinter; Quaternary, Wandersleben dolomite; Middle Triassic) were analysed. The results from our laboratory and on-site studies of the dimension stones show that rocks from the same stratigraphic layer, like the sandstones from the upper Triassic, can show major differences in their petrophysical and weathering properties. These differences are attributed to their different diagenesis, resulting, e.g. in varying pore space, water balance and strength properties. The pore size distribution can be divided into four different groups based on their occurring maxima and micropore content. The determined water balance properties as well as moisture expansion and salt attack depend on these groups. Next to this, the mineralogical composition significantly influences the weathering resistance. Sandstones with a high content of altered lithoclasts show a high amount of moisture expansion, low strength and, in consequence, a low weathering resistance against salt attack. Based on the results of the present study, an evaluation of construction suitability could be accomplished. From the analysed sandstones, only the Seebergen sandstone is suitable for construction purposes due to its good availability, good strength properties (high compressive and
\end{abstract}

H. Stück $(\bowtie) \cdot$ S. Siegesmund · J. Rüdrich

Geoscience Centre of the University Göttingen,

Goldschmidtstr.3, 37077 Göttingen, Germany

e-mail: hstueck@gwdg.de tensile strength, low softening degree) as well as a low porosity. Furthermore, the Wachsenburg sandstone also shows good petrophysical and petrological properties, but exploitable deposits are too sparse to be of commercial interest. From the carbonates, the Wachsenburg sinter shows very suitable rock parameters, but only sparse outcrops occur, which are not appropriate for mining.

Keywords Dimension stones - Sandstones - Carbonates · Weathering

\section{Introduction}

The construction of castles in the Middle Ages only used regionally occurring stones and those easily accessible. One example investigated in this study occurs in the Drei Gleichen area of Thuringia. Three castles named after their respective mountaintops were built on sedimentary rocks (Keuper in age) in the Thuringian Basin (Figs. 1,2). Due to their geological situation and environment, the late Triassic sediments show a wide range of stones with different petrological and petrophysical properties.

During the Middle Ages, natural building stones were mined because of their availability and easy handling, less so according to certain structural and engineering specifications. Stones were extracted, for example, because of their hardness for use as foundation stones or for their workability, especially when stones were used for complex decorative design purposes. Weathering resistance played a rather unimportant role. Today, however, to preserve historical cultural assets, the exact weathering behaviour of a natural building stone has to be defined in terms of structural and engineering qualifications before being used as a replacement stone (Siegesmund and Snethlage 2011). 


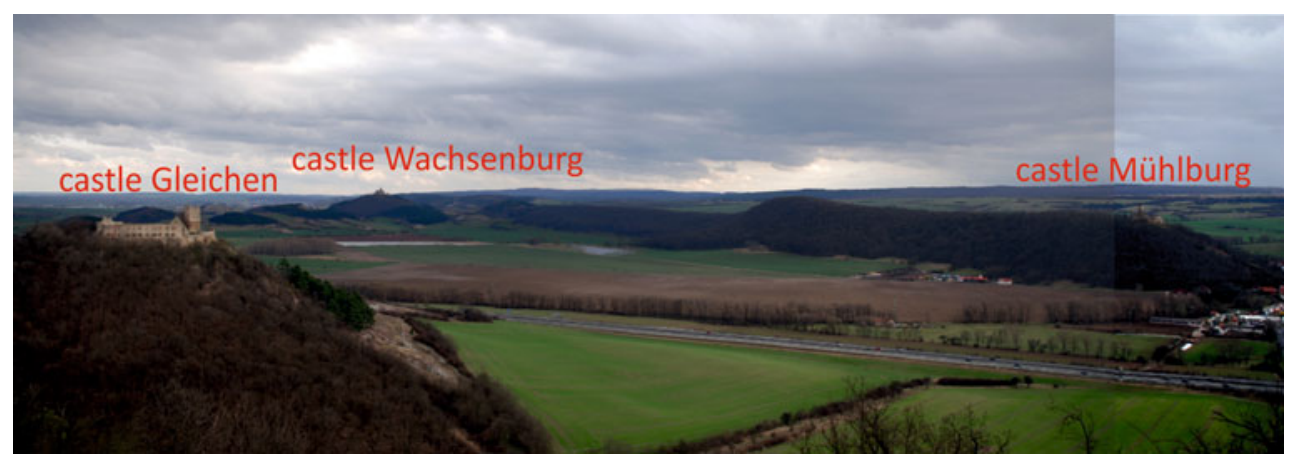

Fig. 1 Overview of the Drei Gleichen area and the buttes consisting of the Rät sandstone. Location of each castle is indicated

Fig. 2 Geological map of the Thuringia Basin and the location of the study area (modified after Puff 1994)

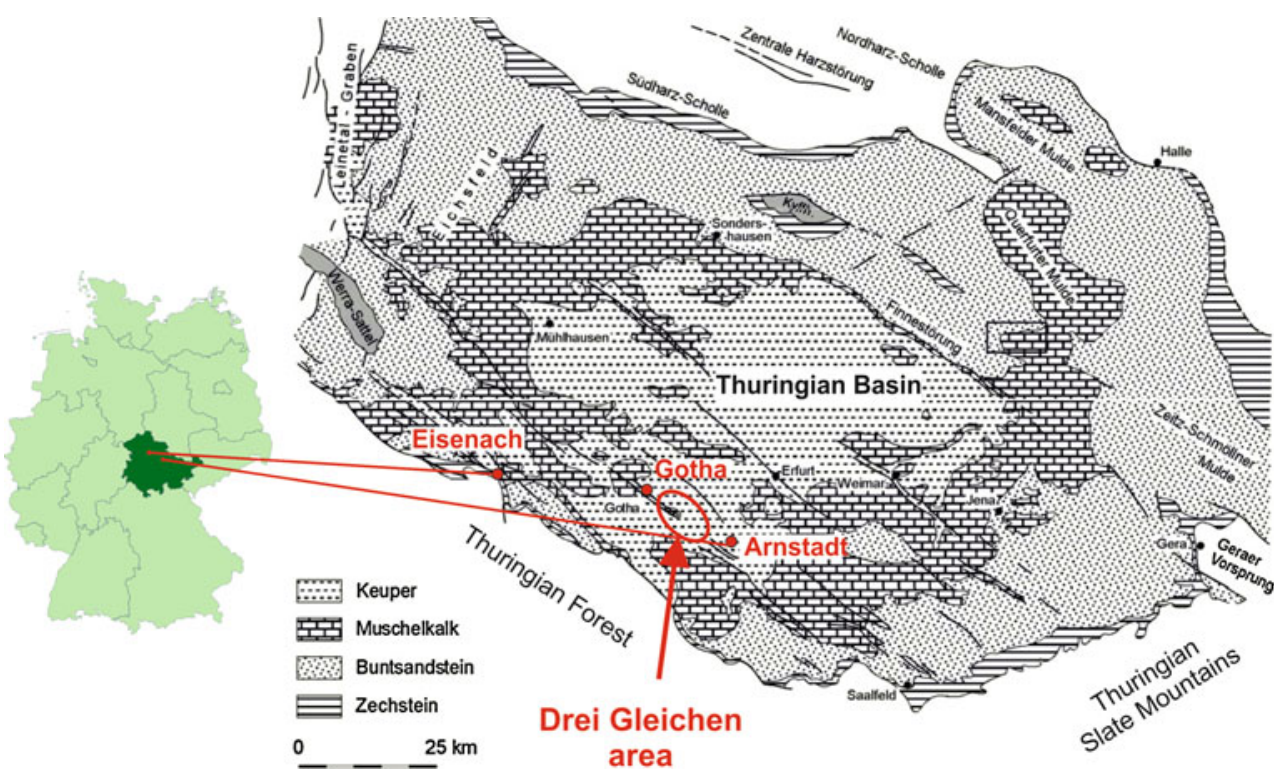

Besides the weathering due to thermal expansion, the moisture expansion as well as salt weathering is especially important for the deterioration of sandstones, which often appear in the Drei Gleichen area. Thermal dilation can occur on every rock and is characterised by a volume change during changing temperature. The intensity of thermal dilation depends on the expansion coefficient of the occurring minerals and also on the arrangement of the single minerals.

In most cases, many damage phenomena can be attributed to the volume increase during moisturisation, which is also known as moisture expansion. The deterioration can be observed as a multiple decay phenomena. Backweathering, related to fabric discontinuities, such as bedding and scaling parallel to the surface, is often observed and induced by hygric swelling. Individual decay phenomena mostly superimpose on each other, where the hygric swelling and salt weathering are caused by the infiltration of deleterious salts from the surrounding mortar. This results in the multiple flaking and efflorescence of salts.
The requirements for a replacement stone depend on the compatibility to the other rocks in the structure and on the mining situation in the area, if the original state of the building is to be reconstructed. The present day mining situation in the Drei Gleichen area for the original stone is concentrated only on the mining of the Seebergen sandstone. The remaining original dimension stones were mined from historical and closed quarries or borrow pits. Therefore, during the restoration work the travertine from Bad Langensalza was also used as a possible restoration stone.

In the present study, the weathering form and deterioration of eight regionally mined stones (Keuper in age) from the Thuringia Basin were investigated at the Castle Gleichen (Gotha, Germany), which is part of the castle ensemble Drei Gleichen. On a selected part of the castle, the type of stones used as well as their particular deterioration was mapped and documented. Furthermore, thin sections were analysed in detail, and pore size distributions of the surface deterioration were determined. To evaluate the structural and engineering specifications of the stones 
used, the petrological and petrophysical properties as well as selected weathering mechanisms were investigated and simulated in the laboratory. The material properties of pore space, water balance and storage, as well as the strength, were determined. For investigating the weathering behaviour, the thermal dilation, moisture expansion and salt loading tests were carried out.

\section{Geological context and building stones of the Drei Gleichen area}

The Drei Gleichen area is situated in the Thuringian Basin (see discussion in Beutler et al. 2010 and Schubert et al. 2010). It extends $10 \mathrm{~km}$ between Arnstadt and Mühlberg in a northwest direction and $3 \mathrm{~km}$ in a southwest to northeast direction (Fig. 2). The outcrops, ranging in age from Lower Muschelkalk up to the Jurassic (Figs. 3, 4), mainly consist of Triassic and are also called "Triassic Land". The redcoloured Middle Keuper is the typical rock type in the area, which forms "together with Upper Keuper" the tops of the castle mountains (Wachsenburg, Mühlburg and Gleichen), along with minor outcrops of the Jurassic (Beutler 1980; Siegesmund et al. 2010).

Deposits and depositional environments of the Drei Gleichen area

The sediments of the German Triassic (Figs. 3a, b, 5) were deposited in the intracontinental German Basin and are divided into lithostratigraphic subgroups of Buntsandstein (red beds), Muschelkalk (chalk) and Keuper (shales). The basin extends from Great Britain to White Russia in a west-east direction and from the Baltic Sea to Bavaria in a north-south direction. This middle European classification is not transferrable to the international classification or the
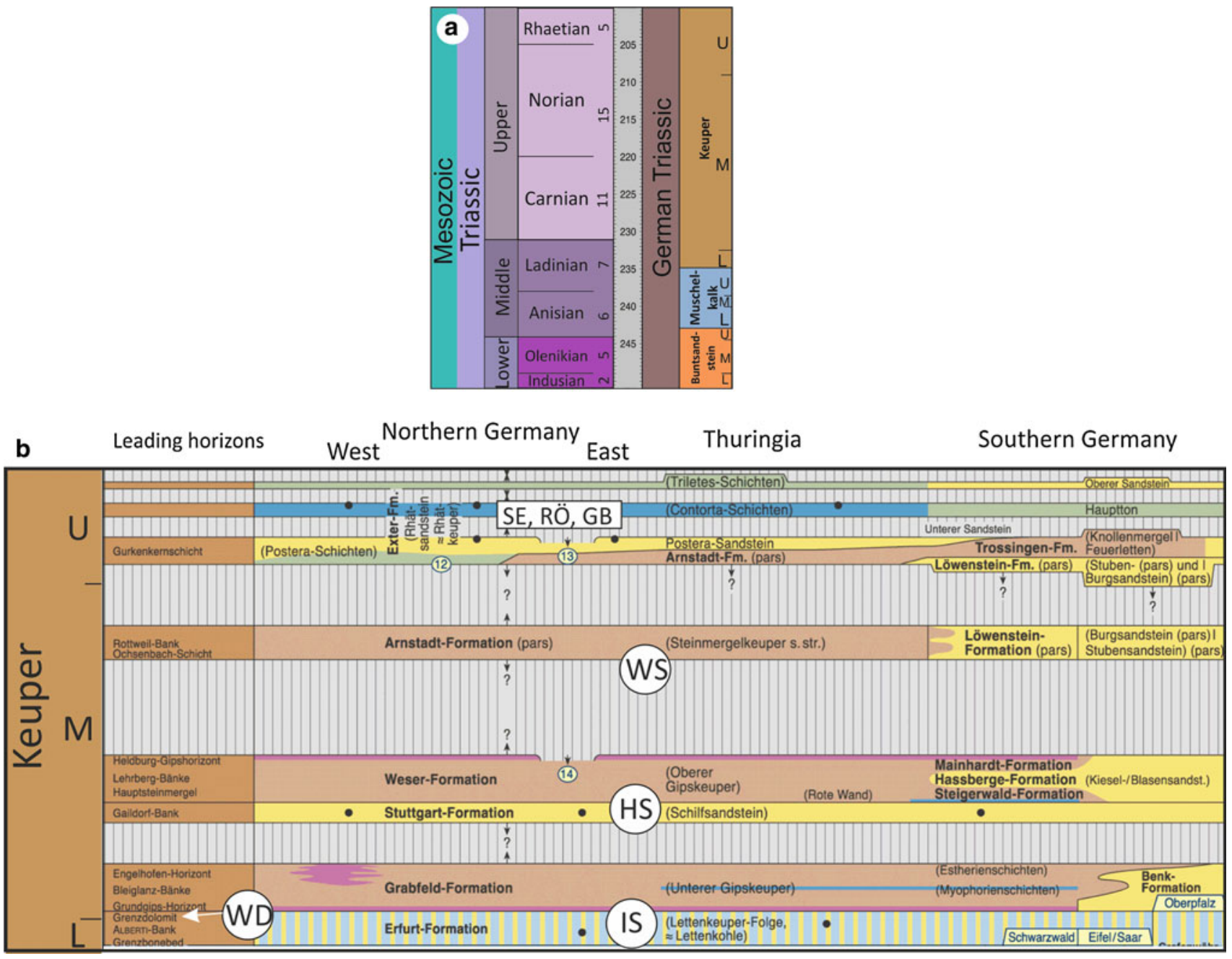

Fig. 3 a Stratigraphic table of the Triassic as well as the German Triassic. b Stratigraphic table of German Keuper in detail with highlighted abbreviations (Table 1) of the occurring dimension stones (changed after Deutsche Stratigraphische Kommission 2002) 


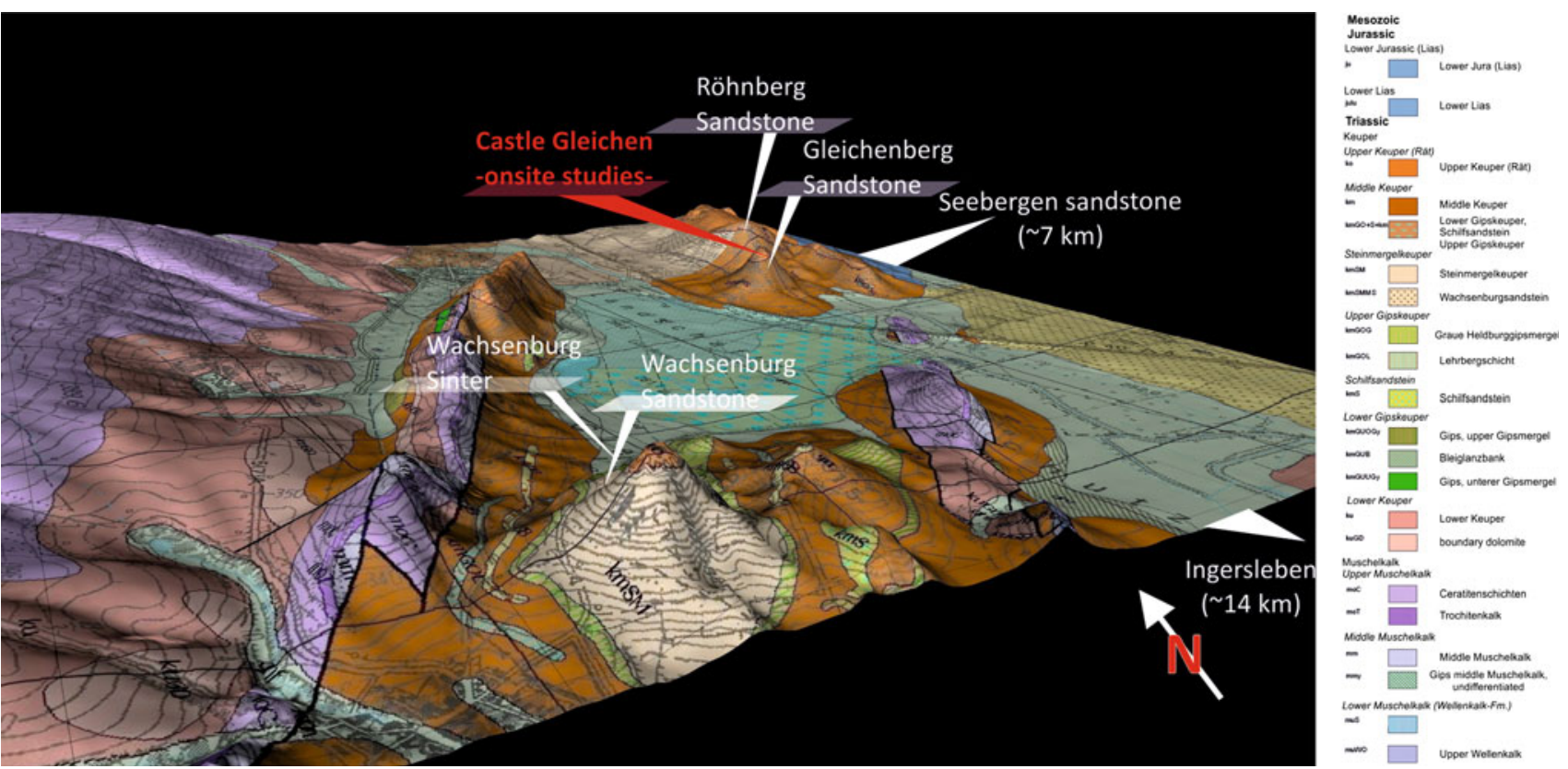

Fig. 4 3-D geologic model of the Drei Gleichen area with the investigated quarries

Table 1 International and German Triassic stratigraphic classification of the investigated sandstones with their mining status

\begin{tabular}{|c|c|c|c|c|}
\hline Name & Abbr. & $\begin{array}{l}\text { Stratigraphic designation } \\
\text { of Thuringian Basin }\end{array}$ & International stratigraphy & Quarry or outcrop \\
\hline Wandersleben dolomite & WD & Grenzdolomite $(\mathrm{ku})$ & 233-235 Ma Ladinium & Glory holes around Wandersleben \\
\hline Ingersleben sandstone & IS & $\begin{array}{l}\text { Lettenkohlenkeuper }(\mathrm{ku}) \sim \\
\text { Erfurt Formation }\end{array}$ & & Quarry Ingersleben, near Erfurt; c.q. \\
\hline Wachsenburg sandstone & WS & $\begin{array}{l}\text { "Semionotus sandstone"/ } \\
\text { Wachsenburg }(\mathrm{km} 1)\end{array}$ & Norium & $\begin{array}{l}\text { Strict limited outcrop near Wachsenburg } \\
\text { (1-m thickness/120-m long) }\end{array}$ \\
\hline Hindfelden sandstone & HS & Schilfsandstein (km2) & 224,5-226 Ma Karnium & Hindfelden near Meiningen; c.q. \\
\hline Seebergen sandstone & SE & Rätsandstein (ko) & 209-200 MaUpper & Multiple quarries Seebergen/Gotha; a.m. \\
\hline Gleichenberg sandstone & GB & & Norium-Rhaetium & Outcrop at Gleichenberg \\
\hline Röhnberg sandstone & RÖ & & & $\begin{array}{l}\text { Quarry at Röhnberg near the Castle } \\
\text { Gleichen; c.q. }\end{array}$ \\
\hline Wachsenburg sinter & WT & Holocene (q), calcareous sinter & & $\begin{array}{l}\text { Multiple borrow pits around } \\
\text { Wachsenburg }\end{array}$ \\
\hline
\end{tabular}

a.m. active mining, c.q. closed quarry

alpine Triassic, which is classified into lower, middle and upper Triassic, based on the occurrence of ammonites. Especially in the Thuringian Basin, the Keuper is classified into regional and locally limited facies. In Fig. 3a and b, the geologic timescale of the German Basin of the Triassic is shown in comparison to the international timescale.

The basin, lying between the $25^{\circ}$ and $35^{\circ}$ northern latitude, is situated in a semiarid area. It is surrounded in the north by the Fenno-Scandinavian Shield and in the south by the Bohemian-Vindelizian Shield where different sediments were deposited (Beutler 1980; Paul et al. 2008;
Wurster1964). During the Buntsandstein, the German Basin was surrounded by the Variscan Orogen, which rapidly eroded due to the arid climate. At the beginning of the Keuper (Lower Keuper), when the former Muschelkalk Sea was regressed, numerous rivers flowed into the basin and deposited large alluvial fans. The transported sediment was deposited at the border of the numerous deltas. The still existing sea with the extension of the Muschelkalk period, eventually flattened out and diminished in size due to the continued deposition, until the basin totally closed. During this time, an extended lagoonal landscape 

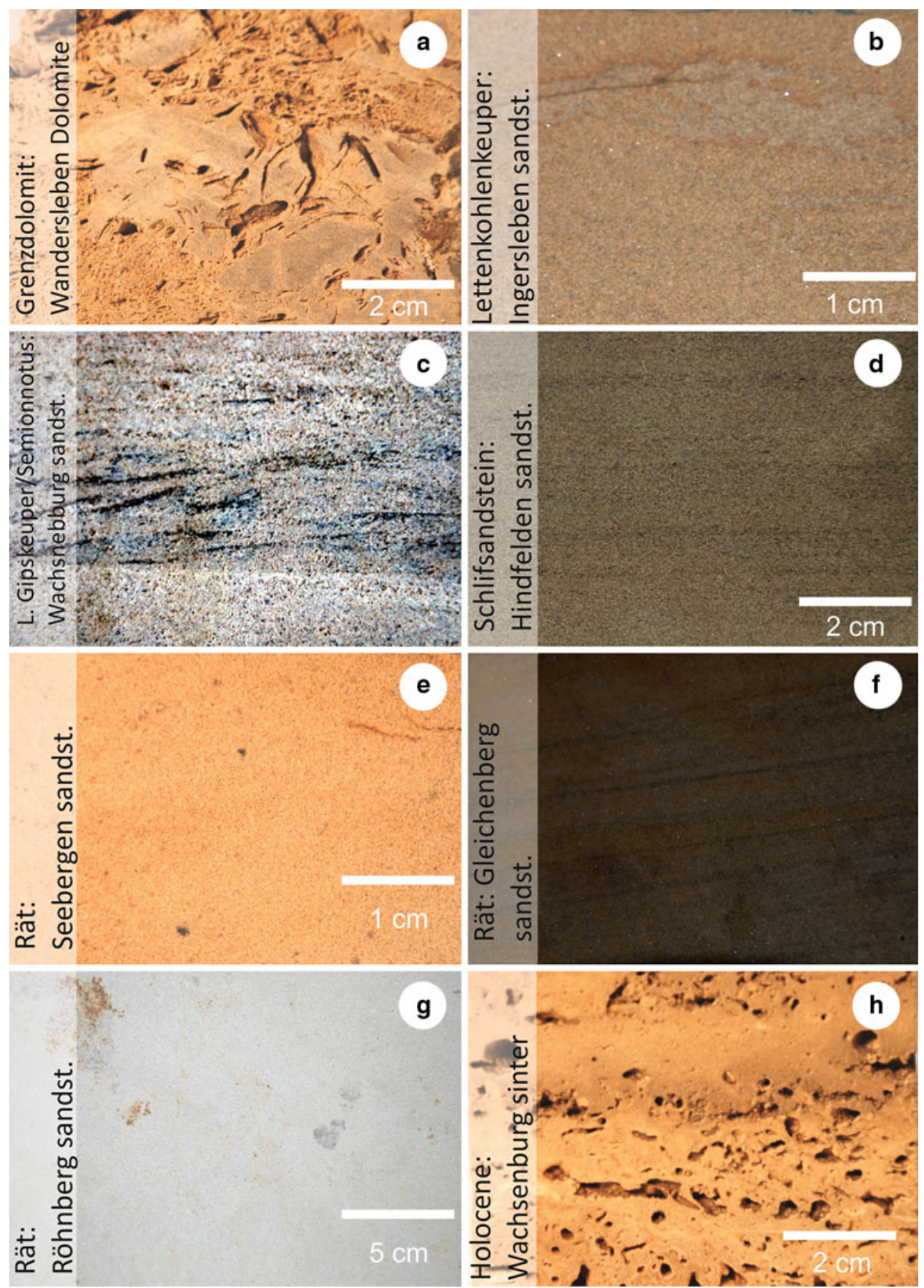

Fig. 5 Macroscopic images of the dimension stones occurring at the Drei Gleichen area. Besides the local name, the stratigraphic designation is also given

developed with diverse vegetation. In the transitional period between the river system and the lagoonal landscape, local moors arose, which are documented by the brackishmarine delta sediments of the Lettenkohlenkeuper (Lower Keuper/Upper Ladinian). Eponymous for this facies is the locally occurring coal layers (Beutler and Schubert 1987; Paul et al. 2008; Wurster1964). One sandstone from this unit was mined near Ingersleben and was used as a common natural building stone in the region (Table 1; Fig. 5b).

Continued deposition caused further subsidence, so that a further transgression took place, thus changing the depositional environment from terrigenous to marine. Carbonates with a low thickness and low fossil content developed. One of these horizons is represented by the 
"boundary dolomite" (Lower Keuper/Lower Ladinian), which not only includes the bivalves such as Costatoria goldfussi but also cephalopods. This stone was also used as a natural building material in the region and was mined near the town of Wandersleben (Table 1; Fig. 5b).

At the beginning of the Middle Keuper (Upper Ladinian-Lower Carnian), a predominant saline depositional environment developed, which is called the interior sabkha. The Middle Keuper begins with the gypsum Keuper, which is overlain by the delta facies of the Schilfsandstein (Carnian $\sim 225 \mathrm{Ma}$ ). Over the flat shelf that was covered by a marine silt layer (Wurster 1964), the delta arms meandered leaving up to $50 \mathrm{~m}$ of fine sand in their channels. The Schilfsandstein was mined as a natural building stone at Hindfelden (near Meiningen, Fig. 5c). A further exception in the mainly dominant saline environment is the thin bedded formation of the Semionotus sandstone at the Wachsenburg (Fig. 4), which is defined by the presence of fresh- and brackish water fish fossils. This sandstone of low thickness was also used as a natural building stone, mainly for the construction of the three castles (Wachsenburg sandstone, Table 1).

The youngest facies of the Middle Keuper is the Steinmergel Keuper (Norium), which is overlain by the Rät sandstones (Upper Keuper/Rhaetian). Locally the facies is also called the Seeberg Formation. These show evidence of changing depositional environments from low marine to lacustrine-terrestrial. The sediments represent alternating beds of fine sands and mudstones (Seidel 2003). The investigated Rhaetian sandstones form the top of the mountains, where the castles are located and were used for their construction. The localities where the Rät sandstones originate are from (Table 1) the Kammerberg at Seebergen (type locality, Fig. 5e), and the mountain of Gleichen (Fig. 5f) and Röhnberg (Fig. 5g). The Seebergen sandstone is still mined today, whereas the quarry at Röhnberg is closed and unapproachable, but still visible at a distance. At Gleichen Mountain, the present mining of the sandstones is not observable.

The Upper Keuper was closed over a period of six million years, ending with a regressive phase and a deposition of limnic mudstones. These were then displaced by the marine sediments of the Lower Lias (Lower Jurassic). At Kallenberg and Röhnberg, a complete stratigraphic sequence from Lias to Dogger (Middle Jurassic) crops out. With the beginning of the Lower Dogger, the sedimentation in the Thuringian Basin ended and was interrupted by a new transgression in the Upper Cretaceous. During the Tertiary and Quaternary, the area was completely eroded. The youngest and also the most recently developed sediments are calcareous sinter (Fig. 5h) and travertines Holocene in age. They were deposited in the lowest part of the Drei Gleichen valley, in a lixiviation depression. The calcareous sinter deposit at Wachsenburg was also used for construction of the castles.

\section{The castles of Drei Gleichen-construction history}

In the present investigation, on-site studies at Castle Gleichen were accomplished. This castle is part of the ensemble "Drei Gleichen", consisting of the castles Mühlburg, Wachsenburg and Gleichen. This ensemble is architecturally very significant, because the structures span the architectural periods from Romanticism to the Renaissance and ending in Historicism. The earliest written reference to a castle in the State of Thuringia is the Castle Mühlburg, which was first mentioned in the year 704 . Castle Gleichen attained fame through the legend of the Earl of Gleichen, who was allowed to have two wives. In 1900, a historically correct construction expanded the size of Castle Wachsenburg (Hobohm 2010; Hopf 2010).

Castle Gleichen only has one tower, where the stonework has been reconstructed within the framework of specific safety margins. All the other castle buildings are in ruins. Only a few areas or parts of the castle walls have been restored over the last several years to ensure their structural integrity. For reconstructing the walls and castle buildings, dimension stones from the immediate surroundings were utilised. These consist of travertine, different formations of Rät sandstone, Semionotus sandstone, Grenzdolomite and limestones. Of special interest are the types of mortars applied in connection with the natural building stones used. Gypsum mortars were applied, which were probably produced from the Heldburg gypsum and Grenzdolomite (Keuper in age) located in the immediate area. Other mortars have also been used in the most recent restoration work and these have led to the development of strong salt efflorescences in the stones.

\section{On-site studies on dimension stones at Castle Gleichen: mapping of lithology and decay phenomena}

The diverse geology of the Drei Gleichen area is suitable for the mining of different dimension stones (Fig. 5). During earlier times, borrow pits as well as quarries were created for the construction of the Drei Gleichen castles on the top of the Rät mountains. Based on their petrophysical properties and their petrogenesis, they also show a very different weathering behaviour as rocks used for dimension stones. To determine whether a possible link among the lithology, petrophysical properties and the weathering behaviour of natural building stones exists from the Drei Gleichen area, the rocks were investigated at one of the castles in the Drei Gleichen area. Since nearly all of the 


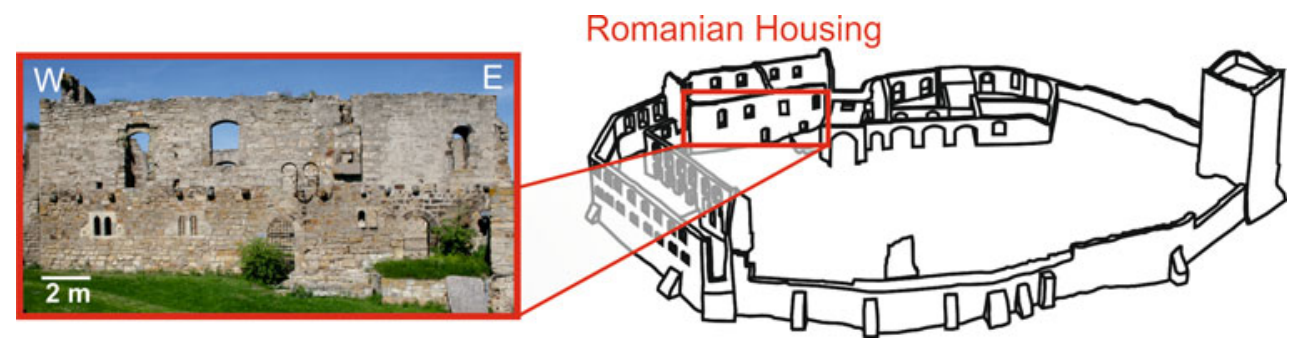

Fig. 6 Schematic drawing of the Gleichen Castle with the mapped wall at the Romanesque residential building

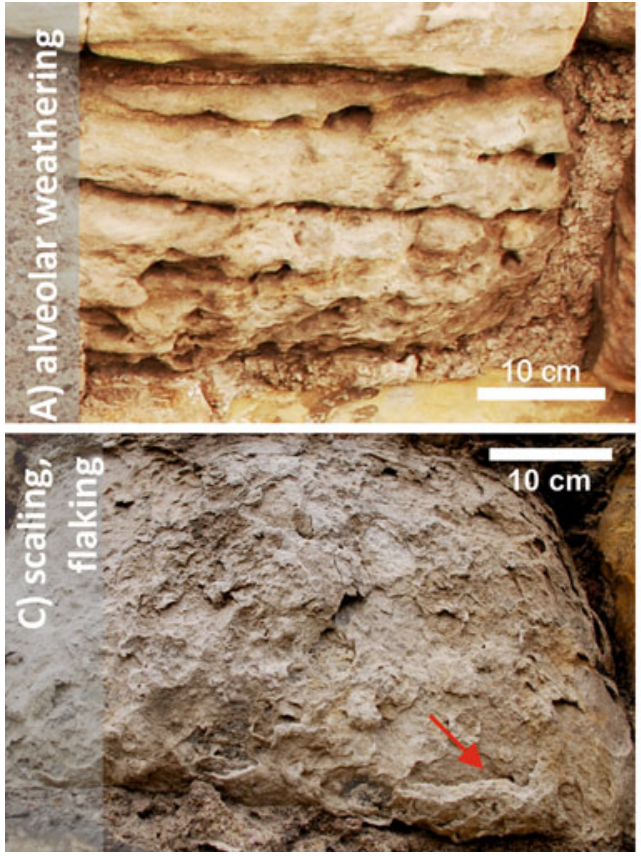

Fig. 7 Selected decay phenomena occurring on dimension stones at the Gleichen Castle. a Alveolar weathering of the Gleichenberg sandstone, $\mathbf{b}$ relief and back-weathering due to the bedding of the

occurring dimension stones of the area are still observable at the Gleichen Castle, the investigation of the different weathering shapes was found to be most suitable at this location. The wall mapped in this study is located in the inner part of the Romanesque residential building and is exposed in a west-east direction (Fig. 6).

After mapping the lithology, all the occurring decay phenomena were classified and divided into categories. With the help of this decay scheme, a mapping of the deterioration was undertaken (see Siedel and Sterflinger 2011).

\section{Categories of decay}

The appearing decay phenomena were classified into the categories of displacement, loss of particles and crustal formation. The occurring phenomena were documented in

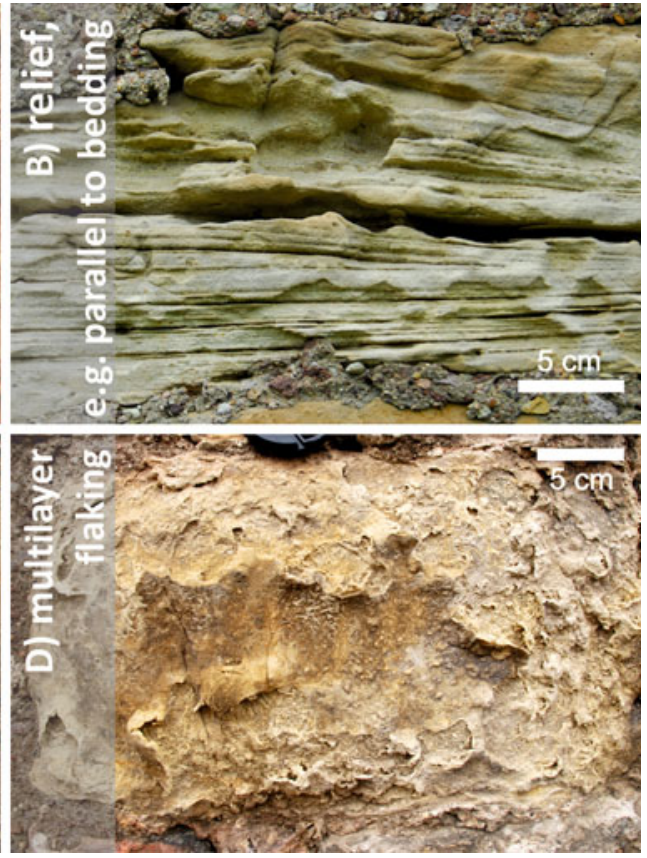

Hindfelden sandstone, c scaling and flaking at the Röhnberg sandstone and $\mathbf{d}$ multilayer flaking of the Gleichenberg sandstone

a map according to their intensity as primary, secondary and inferior shapes (Fig. 9).

In contrast to the displacement of particles, the whole surface was affected by the loss of material. Here, the stone loss was represented by shapes generated from backweathering and relief. The decay phenomenon is a homogenous loss of material parallel to the surface. Relief is defined for all decay phenomena, which cause a heterogeneous loss of material parallel to the surface (Fig. 7a, b). This includes the decay of more resistant areas of the surrounding material. In addition to the rounding of edges and angles, alveolar weathering was also documented as creating relief on the surface (Fig. 7a). The latter is characterised by ellipsoid erosion in the stone.

Detachment includes every change on a rock surface, which is characterised by the peeling of the rock or when the material is still in partial contact with the original 
surface. This also includes sanding, flaking and scaling. Sanding of the surface means the displacement of millimetre-sized particles or smaller. Flaking is the displacement of loose, small centimetre-sized particles, which peel parallel to the surface (Fig. 7c). Sometimes the displacement occurs in a blister-like manner or as a bulging. Scaling includes large-scale displacement parallel to the surface (Fig. 7c). Locally, scales up to $4 \mathrm{~cm}$ in thickness are observable. Furthermore, the flaking and scaling occur in multiple layers over each other, which is mainly observable at the edges of the natural building stones (Fig. 7d). The surface of the scales in general is more lightly coloured than the original intact rock surface.

All decay phenomena, which show a surface accretion of material, belong to the category of crustal deformation. Material accretion is related to visually recognisable changes of the rock surface, including biological settling, crusting and efflorescence. The observed crusts reach a thickness of up to $5 \mathrm{~mm}$.

\section{Mapping of lithology}

From the eight occurring natural building stones in the region, only seven could be observed in the Romanesque residential building (Fig. 8). Two different construction phases were also observable by the particular types of building stones used. In the lower part, almost every occurring rock type was applied in the construction, whereas in the upper part only Wachsenburg sinter was used. Decorating elements were made of the soft and easy to sculpt sandstone from Hindfelden. Rät sandstones were used in the lower part of the wall, which originated from Seebergen, Gleichenberg and partially from Röhnberg.
Wachsenburg sandstone and the Wandersleben dolomite (Grenzdolomite) were also used. The former was applied continuously in a thin line $1 \mathrm{~m}$ up from the bottom, whereas the dolomite was only arbitrarily used (Fig. 8). The Wachsenburg sinters were cut into rectangular forms, whereas the lower part of the wall was constructed from Rät sandstones that were uncut.

\section{Mapping of decay phenomena}

The appearance of decay phenomena (Fig. 9) depends on the lithology and the position of the stone within the wall. For example, the travertine shows just a shallow settling of microbes, which is characterised by a darkened surface. The decay is concentrated in the lower part of the wall, where the various lithologies exhibit the different types of decay structures. The Hindfelden sandstone, which is exclusively used for the decorative elements, mainly exhibits a relief controlled by the bedding. In particular, the iron-rich zones are untouched by the weathering. Close to the bottom of the wall ( $\sim 1 \mathrm{~m}$ above the ground), most of the rocks show crusts, efflorescences and reliefs. The cumulative crusts and efflorescences observable here were probably due to permanent moisture penetration by capillary water entering from the bottom. The salts and crust material most likely originated from the surrounding mortar. Scaling occurred in the lower part, mainly on the Seebergen and Wandersleben sandstone. Directly above the windows, nearly no decay could be observed. However, at the right and left of the windows, highly decayed Rät sandstones with alveolar structures were observable. The Seebergen sandstones often show a previously developed millimetre-thick iron crust on the surface, which are called

Fig. 8 Lithological map of the Romanesque residential building wall

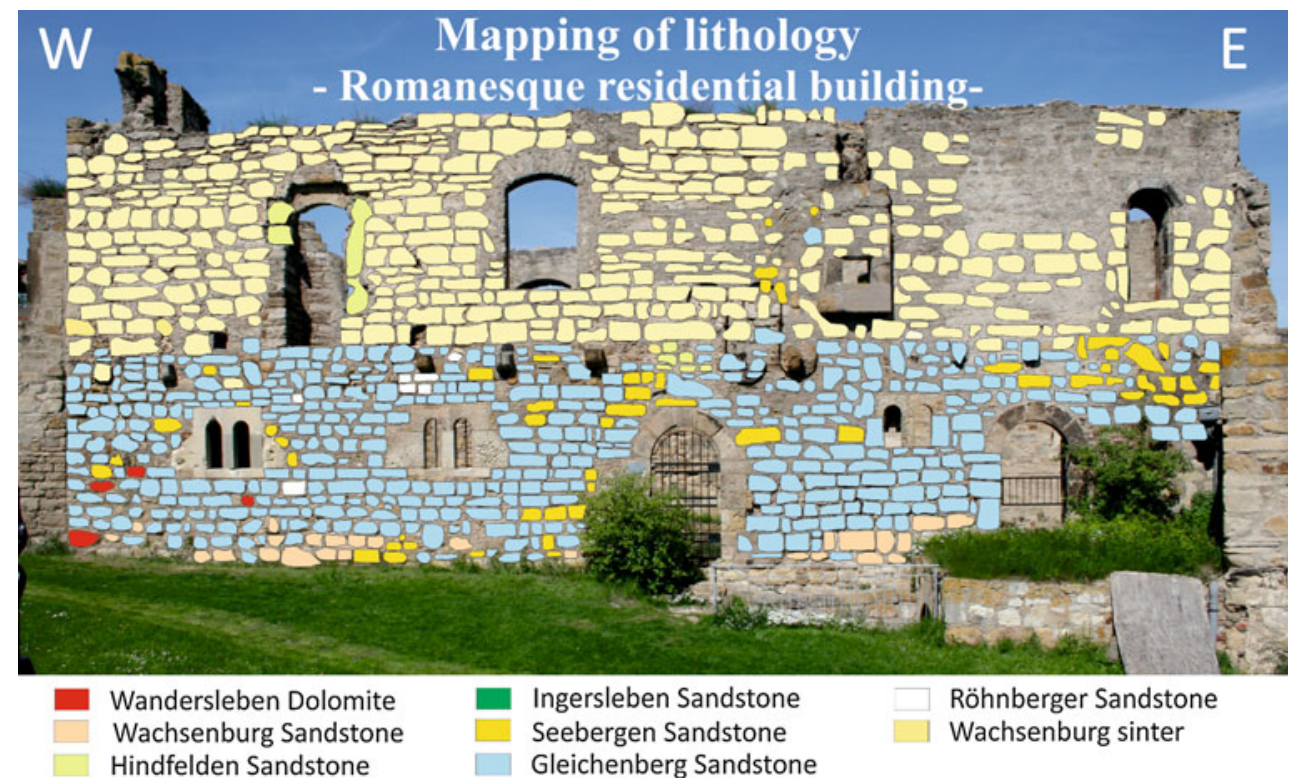


Fig. 9 Mapping of deterioration at the Romanesque residential building wall. The dominant deterioration shapes are completely filled, the secondary ones are striped and the subordinate shapes are indicated with a letter

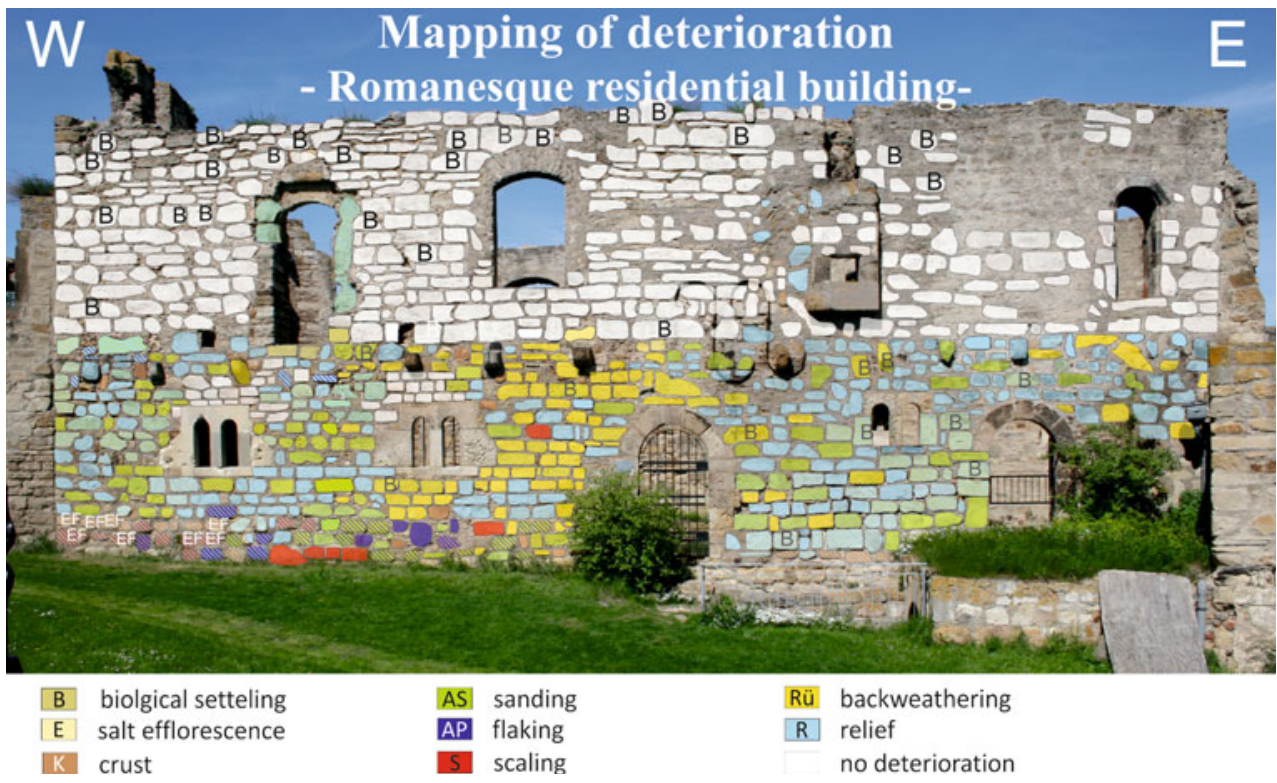

Lower Keuper

liesegang rings. Liesegang rings result from a specific weathering process, caused by the diffusion of iron-rich solutions and the precipitation into deeper parts of the rock. They form concentric rings parallel to the surface and are often linked to joints and cracks.

The isolated and seldom used Wandersleben dolomite is characterised by the back-weathering of the rock's compact and micritic fabric and shows flaking at the rims. Röhnberg sandstones characteristically exhibit sanding and flaking.

\section{Dimension stones: petrology and fabrics}

Understanding the geological setting of sandstones is necessary, when considering their use as a natural building stone. The geological setting affects the mineralogical composition, petrophysical properties and to a certain degree the weathering behaviour of natural building stones.

The investigation of the mineralogical composition and fabric was done by polarisation microscopy, scanning electron microscope and cathodoluminescence. Observations with the scanning electron microscope can reveal information about the pore space properties as well as the crystallisation of new minerals in the pore space, which can influence the petrophysical and weathering properties.

Cathodoluminescence can uncover information about diagenetic processes and the types of cement phases present (e.g. authigenic quartz), which is critical since it can influence the strength properties of a stone. Using this method, different provenance areas of detrital quartz grains can be determined. In the following section, each of the sandstones will be described in their stratigraphic order (Tables 1, 2).
The Wandersleben dolomite represents the youngest cycle in the hanging wall of the Lower Keuper. This horizon crops out in the northeast and southeast of the Wachsenburg Castle (Wandersleben) and shows an approximate thickness of $2 \mathrm{~m}$. The yellowish-brown, highly porous dolomite is characterised by its high content of fossils of up to $8 \mathrm{~mm}$ in size. Microscopic analyses show a sparitic recrystallisation at the fossil rims. The macroscopically visible pores, traced by the hollow space of fossils, only show a weak alignment. Besides the fossil-rich areas, which mainly show a sparitic fabric, a very compact micritic part also occurs (Figs. 10, 11a).

The fine-grained, yellowish-grey sandstone from Ingersleben is characterised by its well-developed bedding ( $\mathrm{mm}$ in thickness) and its accumulation of coaled plant particles on bedding planes. The stone consists of $60 \%$ quartz, $30 \%$ lithoclasts and $10 \%$ feldspars. Subordinated mica also occurs. The pseudomatrix comprises about $20 \%$, with isolated grains occurring in the matrix. The grain contact is sometimes elongated, but point contacts are more prevalent. Quartz grains are subangular and the rock is well graded (Figs. 10, 11c).

\section{Middle Keuper}

The white-rose, fine-grained and cross-bedded Wachsenburg sandstone is partially interstratified with thin coal layers (Fig. 6c). At the bedding surface, mudcracks can be found. The sandstone consists of about $75 \%$ quartz, $20 \%$ feldspar and 5\% lithoclasts. The grain contact is concaveconvex to sutured and the grading is moderate. The quartz 
Table 2 Overview of sandstones investigated: compositional data, grain size, roundness, grain contact, sorting as well as classification after McBride (1963)

\begin{tabular}{|c|c|c|c|c|c|c|}
\hline Sample & $\begin{array}{l}\text { Qtz/Fsp/ } \\
\text { Lithocl. } \\
(\%)\end{array}$ & $\begin{array}{l}\text { Grain } \\
\text { size max } \\
(\mathrm{mm})\end{array}$ & Roundness & Grain contact & Sorting & Classification and comments \\
\hline $\begin{array}{l}\text { Semionotus } \\
\text { sandstone }\end{array}$ & $75 / 20 / 5$ & 0.45 & $\begin{array}{l}\text { Subangular- } \\
\text { angular }\end{array}$ & $\begin{array}{l}\text { Concave- } \\
\text { convex up } \\
\text { to sutured }\end{array}$ & $\begin{array}{l}\text { Well- } \\
\text { moderate }\end{array}$ & $\begin{array}{l}\text { Arkose, strongly altered feldspars, partially calcitic cement, } \\
\text { accretional silica }\end{array}$ \\
\hline $\begin{array}{r}\text { Hindfelden } \\
\text { sandstone }\end{array}$ & $60 / 10 / 30$ & 0.25 & Subangular & Point & Moderate & $\begin{array}{l}\text { Arkositic litharenite, strongly altered feldspars and micas; } \\
\text { micas trace the bedding, chloritised clasts (volcanic) }\end{array}$ \\
\hline $\begin{array}{r}\text { Ingersleben } \\
\text { sandstone }\end{array}$ & $60 / 10 / 30$ & 0.35 & Subangular & $\begin{array}{l}\text { Point- } \\
\text { elongated }\end{array}$ & Well & $\begin{array}{l}\text { Lithic arkose, chlorite: primary and secondary, clay fragments } \\
\text { strong altered feldspar: sericite, epidote, calcite; locally } \\
\text { hematite, mafic clasts altered to chlorite (blue) }\end{array}$ \\
\hline $\begin{array}{l}\text { Seebergen } \\
\text { sandstone }\end{array}$ & $95 / 5 /-$ & 0.25 & $\begin{array}{l}\text { Lightly } \\
\text { rounded- } \\
\text { subangular }\end{array}$ & $\begin{array}{l}\text { Convex- } \\
\text { concave up } \\
\text { to sutured }\end{array}$ & Well & Quartzarenite, lightly goethite overlays of quartz grains \\
\hline $\begin{array}{l}\text { Gleichenberg } \\
\text { sandstone }\end{array}$ & $85 / 10 / 5$ & 0.4 & Subangular & $\begin{array}{l}\text { Elongated- } \\
\text { point }\end{array}$ & Moderate & $\begin{array}{l}\text { Sublitharenite, bedding represented by grain size and material } \\
\text { changes }\end{array}$ \\
\hline $\begin{array}{l}\text { Röhnberg } \\
\text { sandstone }\end{array}$ & $90 / 5 / 5$ & 0.2 & $\begin{array}{l}\text { Rounded- } \\
\text { subangular }\end{array}$ & $\begin{array}{l}\text { Point- } \\
\text { elongated }\end{array}$ & $\begin{array}{l}\text { Very } \\
\text { well- } \\
\text { well }\end{array}$ & Quartzarenite, tangential illite and hematite \\
\hline
\end{tabular}

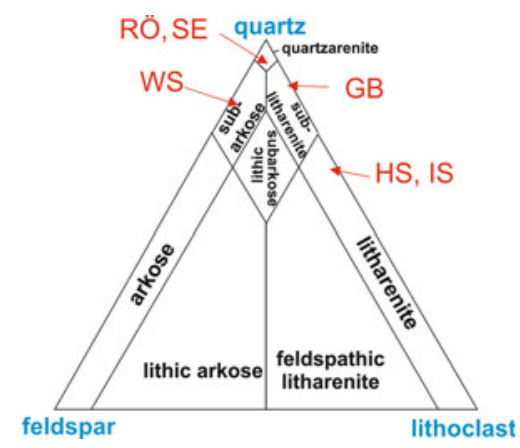

Fig. 10 Classification of the investigated sandstones after McBride (1963); for abbreviations see Table 1

grains are, if not surrounded by quartz cement, subangular to angular. In some areas, the cement is totally composed of silica and in other parts composed of calcite, which induces a very low porosity. Furthermore, the feldspars are mostly altered to clay minerals (Figs. 10, 11e).

\section{Schilf sandstone}

The fine-grained, yellowish-brown silty sandstone of Hindfelden is macroscopically characterised by thin iron oxide layers and thin layers of coaled organic material on the bedding plane. The stone is composed of $60 \%$ quartz grains, $25 \%$ lithoclasts, $10 \%$ feldspar and 5\% mica chlorite. Furthermore, a pseudomatrix comprises $20 \%$ of the rock, which is composed of pelitic lithoclasts. Many clasts are altered to chlorite and are volcanic in origin. The feldspars are strongly altered, and the micas are oriented parallel to the bedding where they developed as kink bands. The quartz grains are subangular, the grains have point contacts and the grading is moderate to well (Figs. 10, 12a).

\section{Upper Keuper-Rät sandstones}

The Rät sandstones represent a group of mature sandstones, enriched in quartz grains, and depleted in feldspars and lithoclasts.

The yellowish, fine-grained sandstone of Seebergen (Fig. 12c) is characterised by local iron oxide precipitations also known as liesegang rings. The stone is composed of $95 \%$ quartz and $5 \%$ feldspar. After the process of quartz cementation, the quartz grains were coated by iron oxides. The grains are somewhat rounded to subangular, the grain contact is concave-convex and the rock is well graded.

The almost white, fine-grained Rät sandstone from Röhnberg (Fig. 12e) is similar to the adjacent Seebergen sandstone, which contains no visible bedding. Spots of dark brown iron precipitations are recognisable. The stone consists of $90 \%$ quartz, 5\% lithoclasts and 5\% feldspar. The subangular grains are surrounded by tangential illite coatings. The grain contact is pointed to elongated, the grading is very well developed and the quartz grains are, with exception at the grain contacts, coated by illites.

The light yellow-grey sandstone from the Gleichenberg (Fig. 12g) is characterised by thin bedding. The sandstone is composed of $85 \%$ quartz, $10 \%$ feldspar and $5 \%$ lithoclasts. The grain contacts are almost concave-convex, but sometimes pointed. The bedding is represented by grain size and material changes. Some areas are fine grained and 


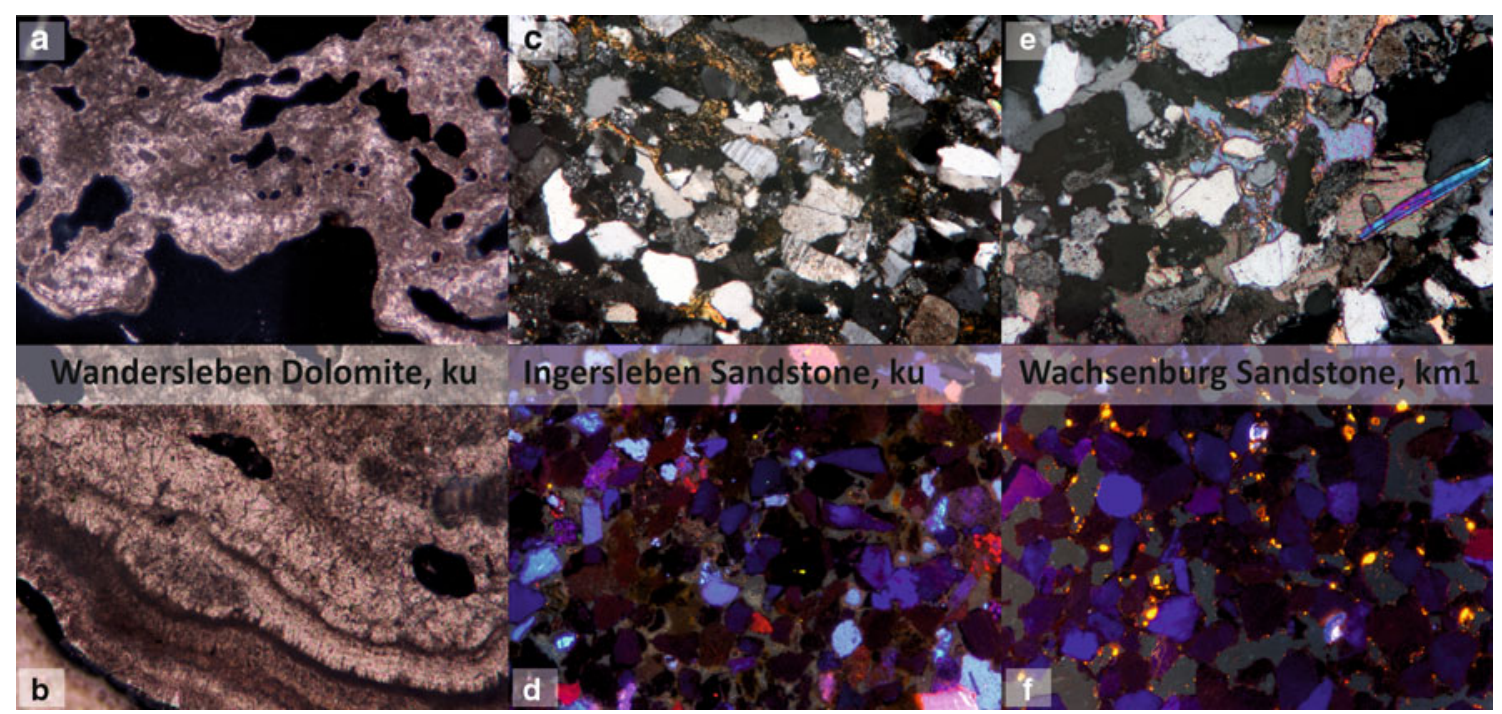

Fig. 11 Thin sections and cathodoluminescence (CL) images of $(\mathbf{a}, \mathbf{b})$ Wanderleben dolomite in thin section, (c, d) thin section and CL-picture of the Ingersleben sandstone and $(\mathbf{e}, \mathbf{f})$ thin section and CL-picture of the Wachsenburg sandstone

rich in micas and clay, while some other areas are coarser grained, with lower mica and clay contents.

\section{Quaternary (Holocene)}

The yellowish-white Wachsenburg sinter is characterised by large-scale pores, which reach a size of up to $5 \mathrm{~cm}$ in length. Furthermore, bedding is observable, which is partially formed by completely calcitised plant stripes. In thin section, the plants and fossils show a sparitic fabric, whereas the surrounding matrix exhibits a micritic fabric (Fig. 13a, b). After Dunham (1962), the sinter can be classified as a wackestone.

\section{Microfabrics of the dimensional stones}

Under cathodoluminescence microscope, the Rät sandstones show more than one provenance of quartz and authigenic quartz in different intensity. Seebergen sandstones contain quartz grains originating from different volcanic, metamorphic and magmatic provenances (Fig. 12d). The authigenic quartz coatings are very common. Röhnberg sandstone consists of two types of quartz, magmatic and volcanic. The authigenic quartz content is very low (Fig. 12f). The quartzes of the Gleichenberg sandstone originate from volcanic and metamorphic areas. The authigenic quartz is common, but mostly dissolute (Fig. 12h). The investigation with the scanning electron microscope shows that the pore space of the Rät sandstones developed differently. Pores, lined with illite coatings (small needles), are observable around the well-sorted quartz grains in the Röhnberg (Fig. 14e) and Seebergen, which has little effect on the porosity but reduces the permeability by blocking the pore throats. Furthermore, a loose packing or grain contact in the Röhnberg (Fig. 14f) and Gleichenberg sandstones is observable, which mainly show point contacts and cubic packing of grains.

Sandstones from Ingersleben and Hindfelden show authigenic quartz cement, where the occurrence is very rare in Ingersleben and very prevalent in the Hindfelden sandstone (Figs. 11d, 12b). Quartz margins are clearly dissolved. The origin of the quartzes and feldspars is different, and the pink colour of feldspars represents a high alteration. Under the scanning electron microscope, the altered lithoclasts or pseudomatrix of the Hindfelden and Ingersleben sandstones show typical fibrous clay minerals (Fig. 14b). Furthermore, hexagonal platelets of kaolinite, which build a network, are observable in the pore spaces of the Hindfelden sandstone (Fig. 14c).

\section{Dimension stones: petrophysical properties}

Next to the petrology and the fabric properties, the size, distribution and the interconnection of the pore space mainly affect the weathering resistance of natural building stones. These properties make them highly relevant for the water balance in rocks (Fitzner 1988; Fitzner and Snethlage 1982; Putnis et al. 1995; Putnis and Mauthe 2000; Siegesmund and Dürrast 2011). Thus, to characterise the structural and engineering qualifications of natural building stones, it is necessary to analyse the pore space properties and its influence on the water transport and retention properties. A further important parameter of a building 


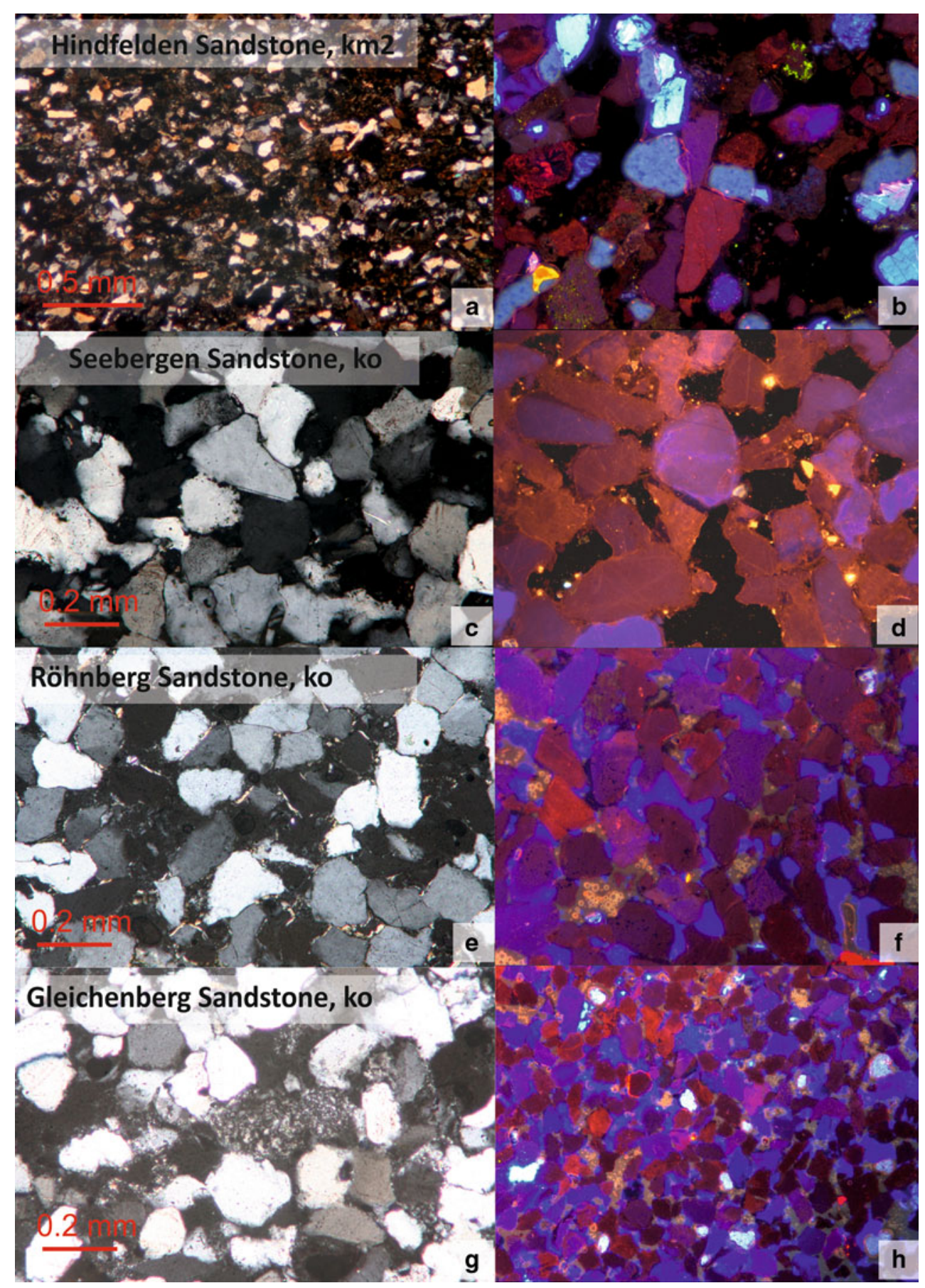

Fig. 12 Thin sections and cathodoluminescence images of (a, b) Hindfelden sandstone, (c, d) Seebergen sandstone, (e, f) Röhnberg sandstone and $(\mathbf{g}, \mathbf{h})$ the Gleichenberg sandstone

stone represents its strength. This parameter is also strongly controlled by the pore space properties (Ruedrich et al. 2010a, b).

To determine the directional dependence of the petrophysical properties, investigations were carried out on specimens from two mutually perpendicular directions parallel ( $X$-direction) and perpendicular ( $Z$-direction) to the bedding. If the specimens did not show any macroscopically visible fabric elements, an arbitrary coordinate system was defined.

Porosity, density and pore size distribution

The porosity and density were determined according to the DIN 52102 (1988). The investigations were carried out on cubic samples with $65 \mathrm{~mm}$ edge lengths. For that purpose, 

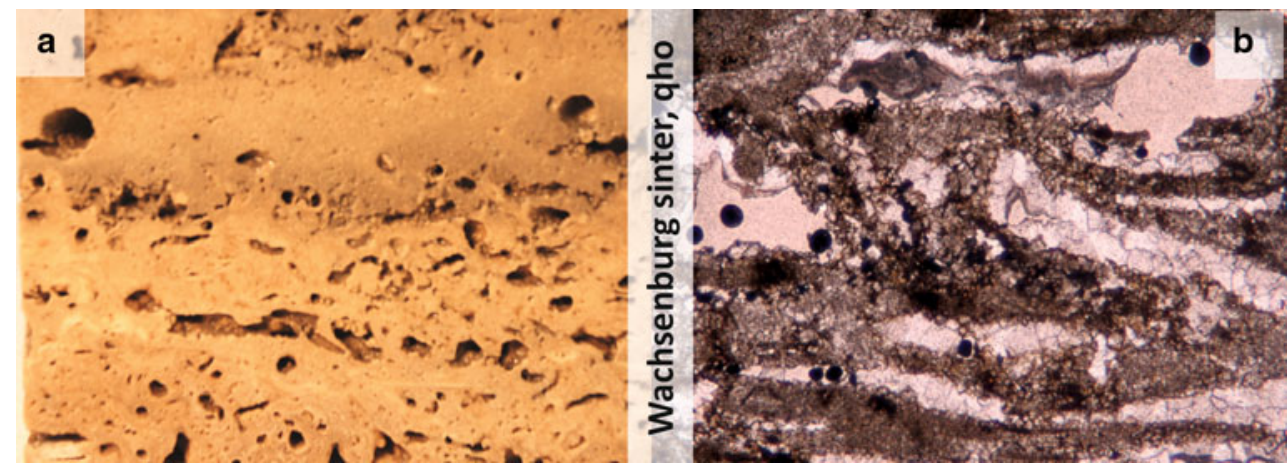

Fig. 13 Macroscopic and microscopic images showing the fabric and microstructures of the Wachsenburg sinter
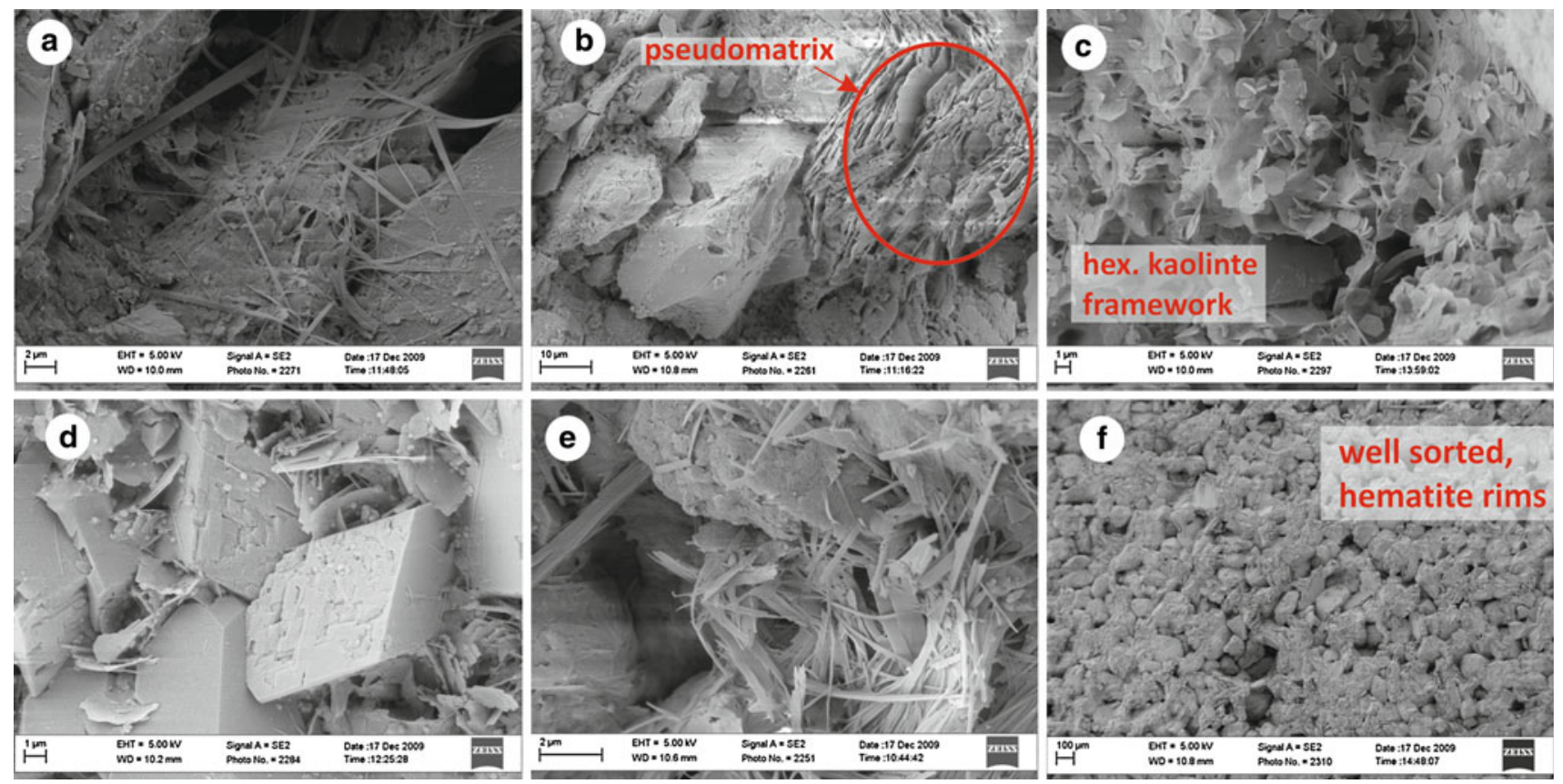

Fig. 14 Scanning electron microscope images of the investigated samples. a Layers of illite over quartz grains in the Ingersleben sandstone. b The highlighted area marks an altered lithoclast in the Ingersleben sandstone. c Network of kaolinite platelets in the

the dry, hydrostatic and water-saturated mass was measured. The dry mass was determined after 2 days of preconditioning the samples at $20^{\circ} \mathrm{C}$ and $15 \%$ relative humidity. The hydrostatic and the saturated mass were detected after water saturation under vacuum.

The porosities of the investigated rocks vary between 8.7 vol.\% and 27.7 vol.\% (Tables 3, 4). This range can be divided into three different porosity classes, low ( $<10$ vol.\%), medium (10-20 vol.\%) and high ( $>30$ vol.\%). The Wachsenburg sandstone shows the lowest porosity with 8.7 vol.\%. Medium porosities are exhibited by the samples from Seebergen (15.80 vol.\%) and the Wachsenburg sinter (16.45 vol.\%). All other samples are characterised by a high porosity ranging from 20.08 to $26.75 \mathrm{vol} . \%$.
Hindfelden sandstone. d Idiomorphic calcite as well as hexagonal kaolinite platelets in the Semionotus sandstone. e Illite needles above a quartz grain in the Röhnberg sandstone. f Overview of the wellsorted Röhnberg sandstone with its loose packing

From the sample masses used for the porosity, the matrix and bulk densities were also calculated (cf. Ruedrich 2010b). The matrix densities were controlled by the rock forming minerals. The sandstones generally show a low matrix density between 2.65 and $2.67 \mathrm{~g} / \mathrm{cm}^{3}$. This correlates with the mineral densities of quartz and feldspar. The Wandersleben dolomites are characterised by a value of $2.88 \mathrm{~g} / \mathrm{cm}^{3}$. The density of the dolomite single crystal is $2.87 \mathrm{~g} / \mathrm{cm}^{3}$ (Tröger 1967), and thus the sample from Wandersleben represents a more or less pure dolomitic rock. In contrast, the Wachsenburg sinter has a matrix density of $2.64 \mathrm{~g} / \mathrm{cm}^{3}$, which is markedly lower than the density of the calcite single crystal $\left(2.72 \mathrm{~g} / \mathrm{cm}^{3}\right)$. This can be traced back to inclusions of material with a lower matrix density. The 
Table 3 Pore size distributions and medium pore radius

\begin{tabular}{|c|c|c|c|c|c|c|}
\hline \multirow[t]{2}{*}{ Pore class $(\mu \mathrm{m})$} & \multicolumn{2}{|l|}{ Micropores } & \multirow[t]{2}{*}{$0.1-1$} & \multirow[t]{2}{*}{$1-10$} & \multirow[t]{2}{*}{$10-100$} & \multirow[t]{2}{*}{ Medium pore radius $(\mu \mathrm{m})$} \\
\hline & $0.001-0.01$ & $0.01-0.1$ & & & & \\
\hline Wandersleben dolomite & 0.00 & 0.00 & 0.00 & 71.60 & 28.40 & 6.87 \\
\hline Ingersleben sandstone & 5.83 & 11.34 & 13.27 & 34.96 & 34.60 & 1.78 \\
\hline Wachsenburg sandstone & 2.80 & 12.58 & 56.48 & 22.47 & 5.67 & 0.52 \\
\hline Hindfelden sandstone & 13.01 & 24.75 & 23.59 & 38.64 & 0.00 & 0.24 \\
\hline Seebergen sandstone & 2.05 & 4.94 & 9.86 & 77.82 & 5.33 & 2.64 \\
\hline Gleichenberg sandstone & 0.00 & 2.72 & 8.45 & 82.88 & 5.95 & 4.42 \\
\hline Röhnberg sandstone & 1.43 & 7.39 & 11.83 & 75.65 & 3.70 & 1.58 \\
\hline Wachsenburg sinter & 20.10 & 21.44 & 12.50 & 25.43 & 20.52 & 0.37 \\
\hline
\end{tabular}

The most occupied pore size given in bold

Table 4 Water transport properties (capillary and hygroscopic water uptake, maximum degree of saturation, water vapour diffusion coefficient) as well as tensile and compressive strength of the specimens

\begin{tabular}{|c|c|c|c|c|c|c|c|c|c|}
\hline & Direct. & $\begin{array}{l}\text { Wandersleben } \\
\text { dolomite }\end{array}$ & $\begin{array}{l}\text { Ingersleben } \\
\text { sandstone }\end{array}$ & $\begin{array}{l}\text { Wachsenburg } \\
\text { sandstone }\end{array}$ & $\begin{array}{l}\text { Hindfelden } \\
\text { sandstone }\end{array}$ & $\begin{array}{l}\text { Seebergen } \\
\text { sandstone }\end{array}$ & $\begin{array}{l}\text { Gleichenberg } \\
\text { sandstone }\end{array}$ & $\begin{array}{l}\text { Röhnberg } \\
\text { sandstone }\end{array}$ & $\begin{array}{l}\text { Wachsenburg } \\
\text { sinter }\end{array}$ \\
\hline Porosity (vol.\%) & - & 23.73 & 27.71 & 8.71 & 22.07 & 15.80 & 21.87 & 22.40 & 16.45 \\
\hline $\begin{array}{l}\text { Matrix density } \\
\left(\mathrm{g} / \mathrm{cm}^{3}\right)\end{array}$ & - & 2.88 & 2.66 & 2.65 & 2.66 & 2.67 & 2.66 & 2.65 & 2.64 \\
\hline $\begin{array}{l}\text { Bulk density } \\
\left(\mathrm{g} / \mathrm{cm}^{3}\right)\end{array}$ & - & 2.20 & 1.92 & 2.42 & 2.07 & 2.25 & 2.08 & 2.05 & 2.21 \\
\hline \multirow{2}{*}{$\begin{array}{l}w \text { value } \\
\quad\left(\mathrm{kg} / \mathrm{m}^{2} \mathrm{~h}^{1 / 2}\right)\end{array}$} & $X$ & 18.56 & 20.05 & 0.75 & 8.50 & 4.17 & 11.85 & 7.50 & 0.81 \\
\hline & $Z$ & 18.94 & 24.21 & 0.98 & 9.98 & 4.90 & 10.03 & 8.01 & - \\
\hline$\mu$ value & - & 10.08 & 5.20 & 39.90 & 10.88 & 22.72 & 5.80 & 6.70 & 18.25 \\
\hline Sorption (\%) & - & 0.18 & 1.43 & 0.40 & 3.00 & 0.16 & 0.50 & 1.50 & 0.23 \\
\hline$S$ value & - & 0.57 & 0.76 & 0.55 & 0.80 & 0.43 & 0.62 & 0.54 & 0.58 \\
\hline \multirow{2}{*}{$\begin{array}{l}\text { Tensile strength } \\
\left(\mathrm{N} / \mathrm{mm}^{2}\right)\end{array}$} & $X$ & 2.37 & 1.03 & 6.04 & 1.12 & 5.5 & 2.99 & 1.54 & 2.94 \\
\hline & $Z$ & 2.76 & 1.43 & 6.57 & 1.89 & 6.01 & 3.91 & 1.58 & 3.01 \\
\hline \multirow{2}{*}{$\begin{array}{l}\text { Compressive } \\
\text { strength/dry } \\
\left(\mathrm{N} / \mathrm{mm}^{2}\right)\end{array}$} & $X$ & 40.07 & 15.21 & 102.14 & 21.55 & 100.82 & 41.54 & 34.03 & 55.34 \\
\hline & $Z$ & 42.63 & 19.59 & 124.41 & 25.68 & 113.07 & 46.07 & 31.64 & 57.08 \\
\hline \multirow{2}{*}{$\begin{array}{l}\text { Compressive } \\
\text { strength/wet } \\
\left(\mathrm{N} / \mathrm{mm}^{2}\right)\end{array}$} & $X$ & 34.89 & 7.98 & 93.75 & 9.81 & 87.67 & 30.48 & 25.46 & 47.56 \\
\hline & $Z$ & 35.12 & 11.57 & 114.69 & 13.45 & 101.57 & 34.50 & 28.54 & 41.14 \\
\hline
\end{tabular}

bulk densities of the investigated rocks show a variation between $1.92 \mathrm{~g} / \mathrm{cm}^{3}$ for the Ingersleben and $2.42 \mathrm{~g} / \mathrm{cm}^{3}$ for the Wachsenburg sandstone. The bulk density was mainly controlled by two parameters: (1) the density of the involved minerals and (2) the porosity of the rock (Table 3 ).

To determine the pore size distribution of the samples, mercury porosimetry was applied (van Brakel et al. 1981). The investigations were carried out with pressures up to $2 \mathrm{kbar}$, which allows the evaluation of pore radii of about $0.005 \mu \mathrm{m}$. Cylindrical specimens $(\varnothing 12.5 \times 20.0 \mathrm{~mm})$ were analysed. The pore size distribution shows a large variation. These different patterns can be divided into four types (Figs. 15, 16): (1) unimodal with one maximum in the range of macropores and a micropore content of $<20 \%$
(Wandersleben dolomite, Ingersleben, Gleichenberg sandstone), (2) unequal unimodal with one maximum in the range of capillary pores and micropore content between 15 and 30\% (Wachsenburg sandstone), (3) unequal bimodal with a high micropore content of 35-45\% (Hindfelden sandstone) and (4) unequal unimodal with one maximum in the range of macropores and a micropore content between 5 and $10 \%$ (Seebergen, Röhnberg sandstone). The calcareous sinter covers a wide range of pore sizes with no significant maximum. The average pore radius of the investigated rocks can be subdivided into: small $(0-1 \mu \mathrm{m})$, medium $(1-2 \mu \mathrm{m})$ and high $(2-5 \mu \mathrm{m})$. The medium pore radius varies from $0.24 \mu \mathrm{m}$ for the Hindfelden sandstone up to $6.87 \mu \mathrm{m}$ for the Wandersleben dolomite (Table 3). 
Fig. 15 Diagrams depicting the pore size distributions in four distinct groups. The average pore radius is marked by the dashed red line. The amount of micropores is also given for each group
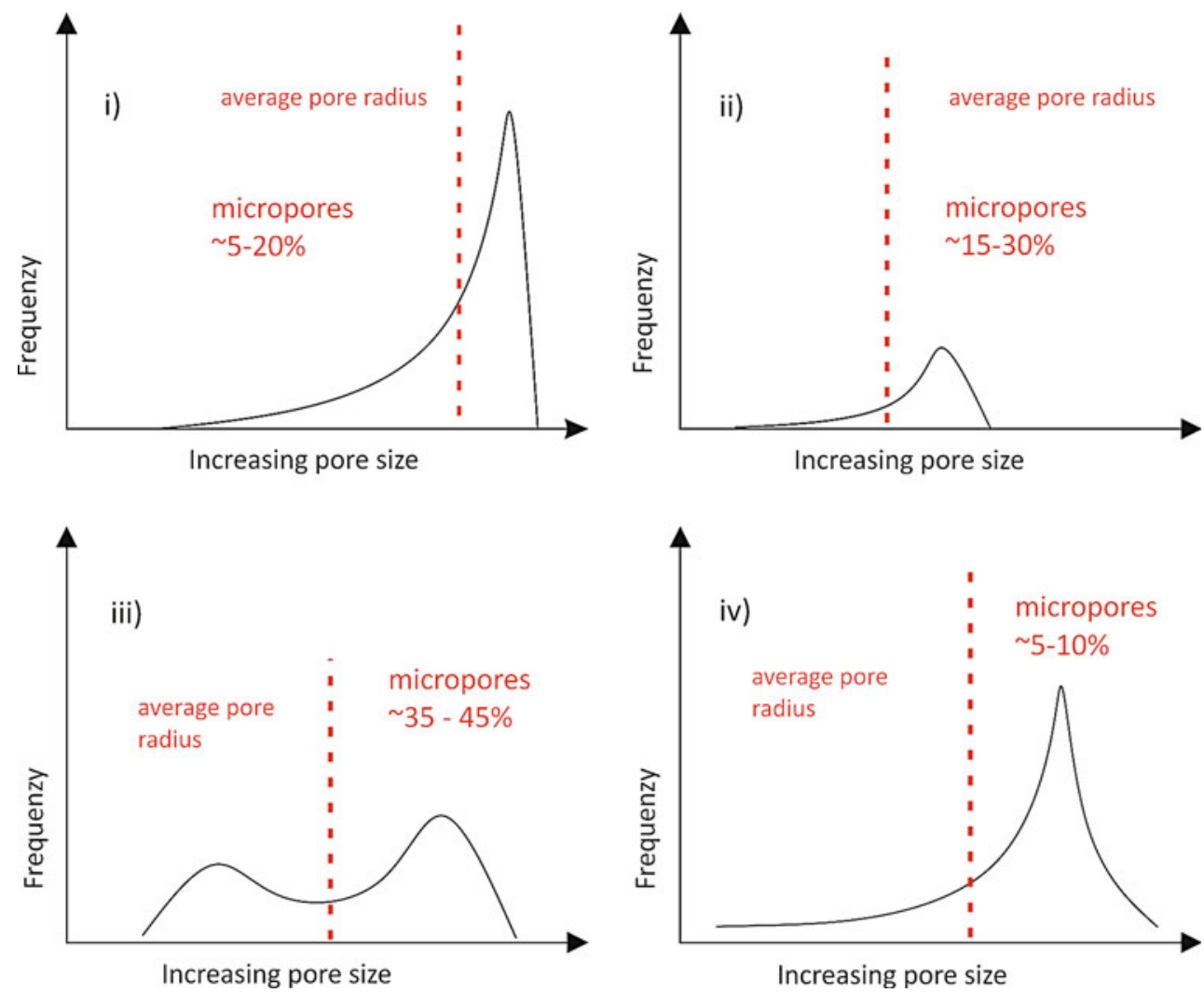

Water transport and retention properties

The water transport and retention properties of a porous natural building stone considerably affect the weathering behaviour. The water balance of rocks were normally described by the parameters of capillary water uptake, sorption and desorption, degree of saturation and water vapour diffusion.

The capillary water uptake was measured according to DIN 52103 (1988) with an underfloor balance, parallel and perpendicular to the bedding. The measurements were performed on sample cubes $(65 \times 65 \times 65 \mathrm{~mm})$, which were dipped $5 \mathrm{~mm}$ in water. The weight increase was digitally measured every $20 \mathrm{~s}$. The capillary water uptake can be expressed by the water absorption coefficient ( $w$ value, Table 4$)$, which represents the absorbed water amount in dependence to area and time $\left(\mathrm{kg} /\left(\mathrm{m}^{2} \sqrt{\mathrm{h}}\right)\right)$. The investigated samples show a wide range of $w$ values from $0.75 \mathrm{~kg} /\left(\mathrm{m}^{2} \sqrt{\mathrm{h}}\right)$ for the Wachsenburg sandstone up to $20.05 \mathrm{~kg} /\left(\mathrm{m}^{2} \sqrt{\mathrm{h}}\right)$ for the Ingersleben sandstone. The highest $w$ values are exhibited by the sandstones from Hindfelden, Ingersleben and the Wandersleben dolomite, followed by the three Rhaetian sandstones, Röhnberg, Seebergen and Gleichenberg. Low to very low $w$ values were detected for the Wachsenburg sandstone and the Wachsenburg sinter. In the case of the sandstones, the $w$ values show a pronounced directional dependence. Generally, the highest $w$ values occur parallel to bedding. The reason for this anisotropy is in most cases a grainshape preferred orientation, which is typical for sandstones (Ruedrich et al. 2010a). In the case of the two carbonates (Wachsenburg sinter and Wandersleben dolomite), the anisotropy is only marginally developed. However, in the Wandersleben dolomite, this can be explained by the small interstitial fossils, which are not aligned parallel to the bedding.

The sorption/desorption was measured in a climate chamber during a stepwise increase of moisturisation between 15 and $95 \%$ relative humidity. Following the relative humidity, a stepwise decrease was performed until the air humidity reached the initial state of $15 \%$. Every humidity stage was held for $24 \mathrm{~h}$. After equilibration the mass of the samples were weighed. Sorption characterises the hygroscopic water uptake and is a degree for the adsorption of water at the internal surfaces of a rock. The stepwise $(10 \%)$ increase and decrease of relative air humidity shows the same progress in all the samples, but the intensity is different (Fig. 17). Between 15 and 80\% relative humidity, the sandstones show a more or less linear weight increase. Above $80 \%$ relative humidity, a surge in weight of the samples occurs. The largest increase is exhibited by the sandstones from Hindfelden and 
Fig. 16 Pore size distributions in the investigated sandstones. The red letters represent the previously explained groups of pore size distribution
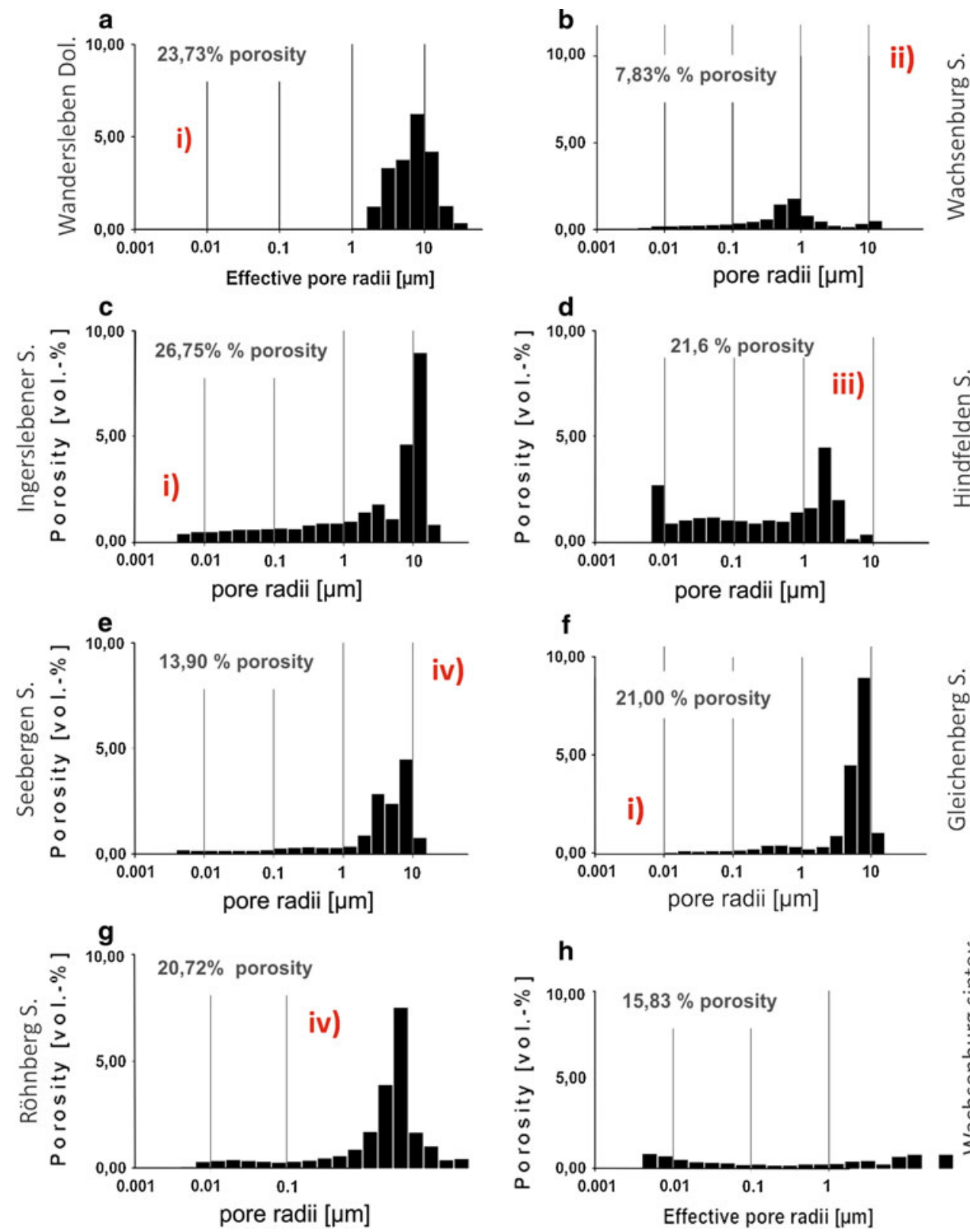

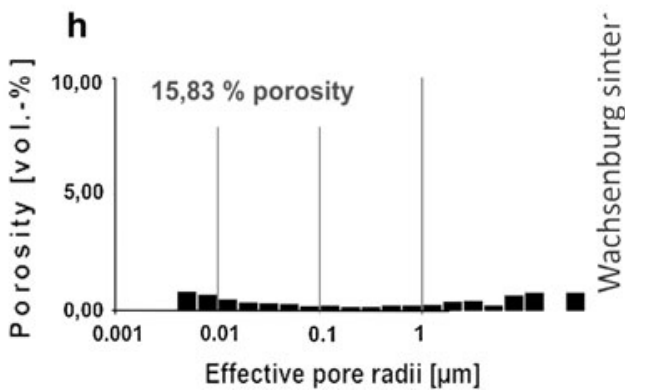

Ingersleben. All the other samples show with one percent maximal weight increase (at 95\%) a very low hygroscopic water uptake (Table 4).

The degree of saturation depends on the pore sizes and the interconnection of the pores. The presence of cements can clearly affect the permeability of sandstones. The degree of saturation covers a range from 0.43 for the Rät sandstone of Seebergen to 0.8 for the silty sandstone of Hindfelden (Table 4).

The water vapour diffusion coefficient was determined with the "wet-cup" method according to DIN 52615 (1987) and was carried out on disc-shaped samples $(40 \times 10 \mathrm{~mm})$. The rim of the specimens were sealed up with an adhesive strip and closed over a Teflon fryer. The measurement was accomplished at $20^{\circ} \mathrm{C}$ and $50 \%$ relative humidity in a climate chamber. The change in weight of the water filled Teflon cup was measured in 24-h intervals.

The water vapour diffusion ( $\mu$ value) is a measure of the vapour diffusion through the rock and is mainly controlled by the pore size distribution (Ruedrich et al. 2010a). The non-dimensional $\mu$ values vary from 9 to 49 (Table 4), which indicates only slight differences between the rocks.

Tensile and compressive strength

Strength properties such as tensile strength and compressive strength are important rock parameters, which also influence the weathering behaviour of dimension stones. 
Fig. 17 Sorption/desorption in dependence to relative air humidity of a Ingersleben sandstone, b Hindfelden sandstone, c Seebergen sandstone and $\mathbf{d}$ Röhnberg sandstone. Red line adsorption, blue line desorption
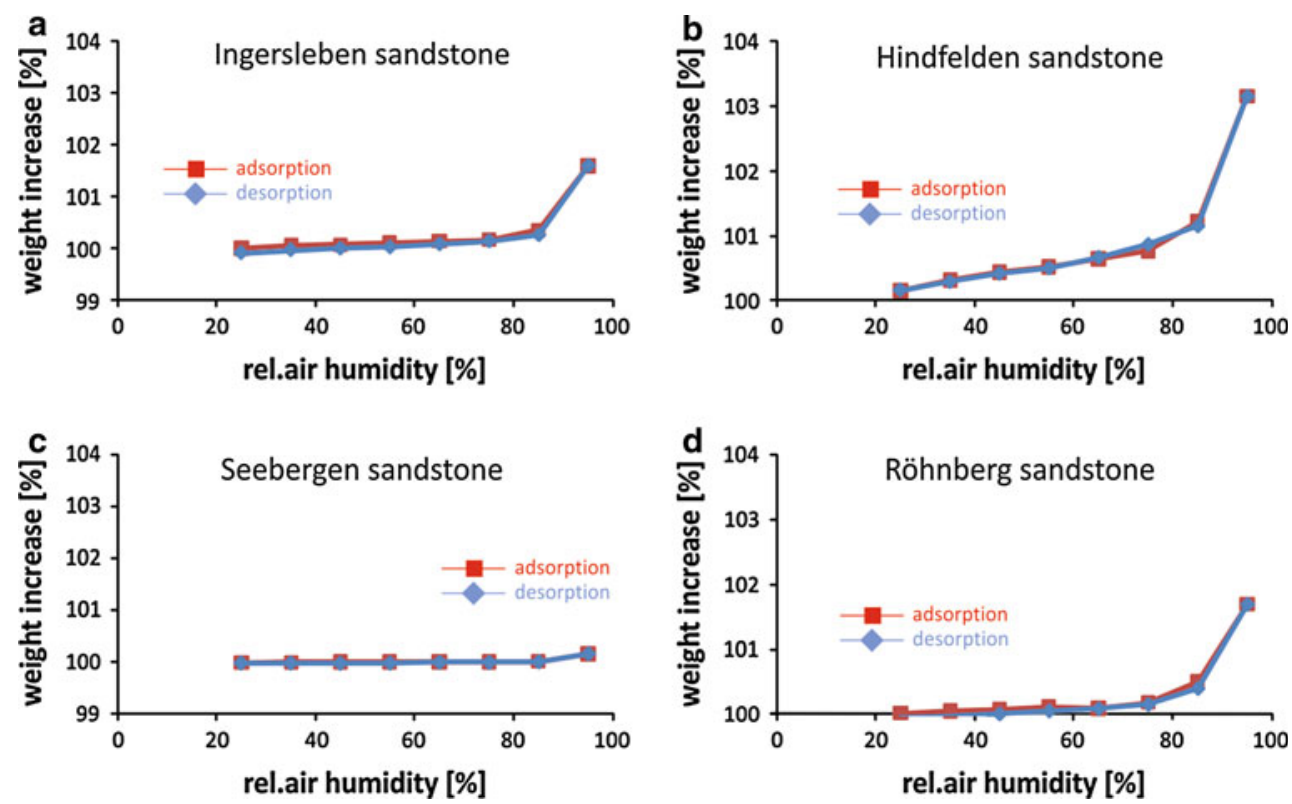

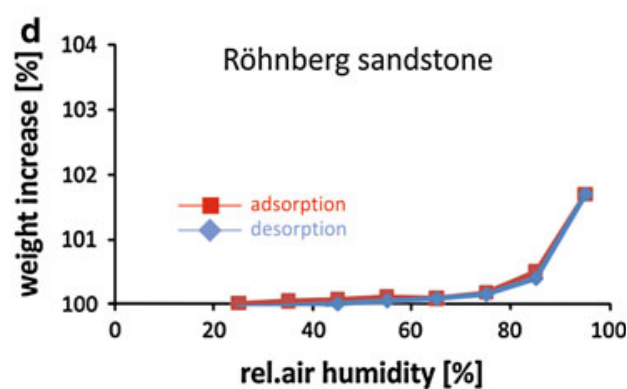

The cause for this is that stresses induced by mechanical weathering processes have to exceed the strength of a material before a failure occurs. Thus, the strength properties are a measure for the grain fabric cohesion. Important fabric parameters for the tensile strength are the grain size, the shape of the grain contacts and a preferred grain boundary orientation. However, of most significance is the type and intensity of cementation.

To obtain the values of tensile strength, measurements were made using the Brazil test according to DIN 22024 (1989). The investigations were performed on disc-shaped specimens $(40 \times 20 \mathrm{~mm})$. By loading the discs in parallel lying surface lines, a tensile strength is induced in the sample perpendicular to the applied pressure. The tensile strength of the sandstones ranges from $1.23 \mathrm{MPa}$ to $6.64 \mathrm{~N} / \mathrm{mm}^{2}$ (Table 4). The Wachsenburg and the Seebergen sandstones show high values of 6.24 and $6.63 \mathrm{~N} /$ $\mathrm{mm}^{2}$, whereas Hindfelden, Ingersleben and Röhnberg only exhibit low tensile strength values up to $2 \mathrm{MPa}$. The remaining samples show a medium strength. The anisotropy of all the rocks is not very well pronounced.

The uniaxial compressive strength was measured on cylindrical samples $(50 \times 50 \mathrm{~mm})$ with coplanar end faces (accuracy of $0.1 \%$ ) in the dry and water-saturated state. The load was applied to the end faces of the specimen with a strain rate of $1,000 \mathrm{~N} / \mathrm{s}$ until failure. The compressive strength varied between 16.97 and $113.27 \mathrm{~N} / \mathrm{mm}^{2}$ (Table 3). The highest compressive strength in the dry sample state was exhibited by the Wachsenburg sandstone, followed by the Rhaetian sandstones. The compressive strength in the water-saturated state ranged from $7.98 \mathrm{~N} /$ $\mathrm{mm}^{2}$ for sandstone Ingersleben and $93.75 \mathrm{~N} / \mathrm{mm}^{2}$ for Wachsenburg sandstone (parallel to bedding/Table 4).

\section{Laboratory weathering tests}

The dimension stones show in a natural environment a manifold deterioration (see Chapter 4). Several weathering mechanisms are assumed to be responsible for the actual state of the rocks. In general, the weathering can be divided into chemical, physical and biological processes, whereby the single mechanisms overlap each other and lead to multifarious deterioration.

To determine and evaluate the weathering behaviour of the dimension stones from the Drei Gleichen area, thermal dilatation, moisture expansion and salt weathering were simulated and accomplished in the laboratory.

Thermal dilation

During changes in temperature, all rocks show a change in volume, which results from the increasing movement of the atoms of minerals during heat input. Natural building stones are exposed to continuous temperature fluctuations during the cycles of day and night. Thermal dilation was measured by heating the samples from 20 to $90^{\circ} \mathrm{C}$ followed by a cooling down to $20^{\circ} \mathrm{C}$. The length change was detected by an incremental displacement transducer with an accuracy of $1 \mu \mathrm{m}$.

All the samples are characterised by an expansion with increasing temperature and during cooling a contraction (Fig. 18). The path of the curves proceeds differently: Some samples, such as Seebergen and Semionotus, show a more or less linear progression, whereas other samples show a distinct departure from this linear path. During heating at temperatures ranging between 55 and $85^{\circ} \mathrm{C}$, some of the curves clearly show a flattening. This is 
Fig. 18 Length change $(\mathrm{mm} / \mathrm{m})$ of samples investigated dependent on the temperature

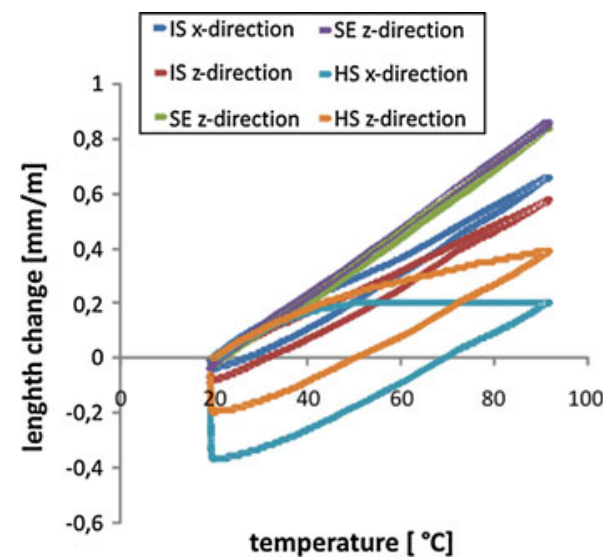

especially the case for the Hindfelden sandstone, which does not show a linear progression. When reaching a temperature of $55^{\circ} \mathrm{C}$, the path runs parallel to the abscissa. Furthermore, at reaching the initial temperature of $20^{\circ} \mathrm{C}$, some samples show shrinkage, but different intensities occur based on rock types.

The intensity of thermal dilation mainly depends on the types of minerals present and can be expressed by the thermal expansion coefficient (Table 5). The coefficients of the investigated sandstones are very similar, with the exception of the sandstones from Ingersleben and Hindfelden. The mineralogical composition affects the thermal dilation, especially swellable clay minerals, and at least altered lithoclasts and pseudomatrix, enriched in swellable clay minerals. All the four sandstones mentioned above have a high content of altered lithoclasts or pseudomatrix, which also show a departure from the linear progression.

All the samples investigated exhibit an anisotropy, which is very well pronounced in the case of the altered lithoclasts in the stones of Hindfelden and Ingersleben sandstone. The contraction during heating, resulting from clay mineral shrinkage, strongly depends on the kind of clay mineral present. The shrinkage intensity is well pronounced in the case of the Ingersleben and Hindfelden sandstones. These all contain a high amount of altered clay-rich lithoclasts.

\section{Moisture expansion}

In many cases, moisture expansion is held responsible for the damages visible in rocks. The swelling and shrinking during changing moisturisation can induce stresses within the rock fabric. In the course of time, this leads to a breaking up of the grain cohesion. Moisture expansion can occur for almost every type of rock (Weiss et al. 2004, Ruedrich et al. 2010a, Siegesmund and Dürrast 2011). However, porous rocks with certain clay mineral content
Table 5 Thermal expansion coefficients and shrinkage $(\mathrm{mm} / \mathrm{m})$ after measuring

\begin{tabular}{|c|c|c|c|}
\hline & $X$-direction & Z-direction & $\begin{array}{l}\text { Shrinkage } \\
(\mathrm{mm} / \mathrm{m})\end{array}$ \\
\hline \multicolumn{4}{|c|}{ Thermal expansion coefficient $\alpha(\mathrm{K}-1)$} \\
\hline Wandersleben dolomite & $8.04865 \mathrm{E}-06$ & $8.013462-06$ & - \\
\hline Ingersleben sandstone & $9.0391 \mathrm{E}-06$ & 7.9079E-06 & 0.08 \\
\hline Wachsenburg sandstone & $9.9448 \mathrm{E}-06$ & $1.00715 \mathrm{E}-05$ & 0.02 \\
\hline Hindfelden sandstone & $2.7675 \mathrm{E}-06$ & $5.418 \mathrm{E}-06$ & 0.35 \\
\hline Seebergen sandstone & $1.1658 \mathrm{E}-05$ & $1.183 \mathrm{E}-05$ & 0.01 \\
\hline Röhnberg sandstone & $1.1481 \mathrm{E}-05$ & $1.1935 \mathrm{E}-05$ & 0.02 \\
\hline Gleichenberg sandstone & $1.15379 \mathrm{E}-05$ & $1.19331 \mathrm{E}-05$ & 0.02 \\
\hline Wachsenburg sinter & $8.46775 \mathrm{E}-06$ & $8.127656-06$ & - \\
\hline
\end{tabular}

like sandstones show pronounced moisture expansion wetting. Pore spaces with a high content of micropores, in combination with clay minerals (partly swellable) at least in the lithoclasts, is probably responsible for the intensity of this weathering process (Ruedrich et al. 2010a).

In the present study, moisture expansion was measured under water-saturated conditions (hydric wetting). The investigations were carried out on cylindrical samples $(100 \times 15 \mathrm{~mm})$. A preconditioning of the specimens was achieved by drying in a climatic chamber at $20^{\circ} \mathrm{C}$ and $15 \%$ relative humidity. The final resolution of the displacement transducers was better than $0.5 \mu \mathrm{m}$.

The measured swelling during water absorption of the rocks varies from $0.015 \mathrm{~mm} / \mathrm{m}$ for the Wachsenburg sinter to $5.2 \mathrm{~mm} / \mathrm{m}$ for the Hindfelden sandstone (both measured parallel to the $Z$-direction, Table 6). In general, quartz-rich rocks like the Rät sandstones show only slight moisture expansion, whereas rocks with a high content of altered lithoclasts like the Hindfelden and Ingersleben sandstones are characterised by large values of moisture expansion.

All investigated rocks show a directional dependence of moisture expansion. The expansion perpendicular to the 
Table 6 Moisture expansion at water saturation $(\mathrm{mm} / \mathrm{m})$

\begin{tabular}{llll}
\hline Sample & $X$-direction & $Y$-direction & $Z$-direction \\
\hline $\begin{array}{l}\text { Moisture expansion }(\mathrm{mm} / \mathrm{m}) \\
\text { Wandersleben dolomite }\end{array}$ & 0.175 & 0.180 & 0.190 \\
Ingersleben sandstone & 0.500 & 0.290 & 1.800 \\
Wachsenburg sandstone & 0.120 & 0.050 & 0.130 \\
Hindfelden sandstone & 2.400 & 1.800 & 5.200 \\
Seebergen sandstone & 0.010 & - & 0.020 \\
Gleichenberg sandstone & 0.110 & 0.080 & 0.470 \\
Röhnberg sandstone & 0.130 & 0.090 & 0.190 \\
Wachsenburg sinter & 0.016 & 0.015 & 0.015 \\
\hline
\end{tabular}

bedding is in general more pronounced than parallel to the bedding. Sandstones with a distinct bedding show a wellpronounced anisotropy, such as the rocks from Gleichenberg, Ingersleben, Hindfelden and also Wachsenburg.

\section{Salt attack test}

In order to determine the weathering resistance of the investigated samples against crystallisation of salt within the pore space, salt attack tests were performed according to the German VDI 3797. Cubic samples (65 mm edge length) were saturated with a solution of $10 \% \mathrm{NaSO}_{4}$ at different cycles. After $6 \mathrm{~h}$ of saturation the samples were dried at $60^{\circ} \mathrm{C}$ for $16 \mathrm{~h}$. Afterwards, the samples were weighed and the macroscopic damages were photographically documented. The experiment was completed after a maximum of 15 cycles. The sample weights as well as the surface consistency of all the rocks were changed by the salt attack test. All samples show after the first test cycle a slight weight increase. This can be traced back to crystallisation of salt within the pore spaces of the rocks without damaging effect. For the following cycles a rock specific weight decrease is observable. This is strong for the
Ingersleben sandstone and very slight for the Wachsenburg sinter (Fig. 19).

The decay phenomena observed are different in shape and intensity, and are also specific for each rock. For the Röhnberg and Ingersleben sandstone a first loss of material is observable after the third test cycle. The visible decay phenomena are sanding at the edges, which lead to a rounding of the samples. Furthermore, a crack formation is detectable for the rocks from Röhnberg. In contrast, the Ingersleben sandstone shows a higher variation in the type of decay, besides sanding and rounding, scaling, flaking as well as back-weathering of iron-rich areas occur. The Hindfelden sandstone as well as the Wandersleben dolomite reached a $10 \%$ loss of material after five to six cycles. Therefore, the Hindfelden sandstone exhibits a similar decay pattern as the Ingersleben rock. For the Wandersleben dolomite, a back-weathering of the fine-grained, micritic and fossil-rich areas are observable. After ten cycles, the Hindfelden and Ingersleben sandstones as well as the Wandersleben dolomite show a highly rounded and globular shape. In contrast, the Seebergen sandstone exhibits a better salt attack resistance. The rock only shows slight sanding and rounding. The Wachsenburg sinter shows the best weathering resistance within the test. After reaching the 15th cycle, the sample exhibits more or less no loss of material. Also, no decay phenomena are observable.

\section{Discussion and summary}

The geology of the Drei Gleichen area is dominated by sediments of the Late Triassic age. This sedimentary sequence is characterised by a high diversity of different rock types, where some of the rocks are also suitable for use as dimension stones. Of lesser importance are the younger rocks (Quaternary in age), which mainly occur as exposed outcrops in the floodplain. Regionally quarried
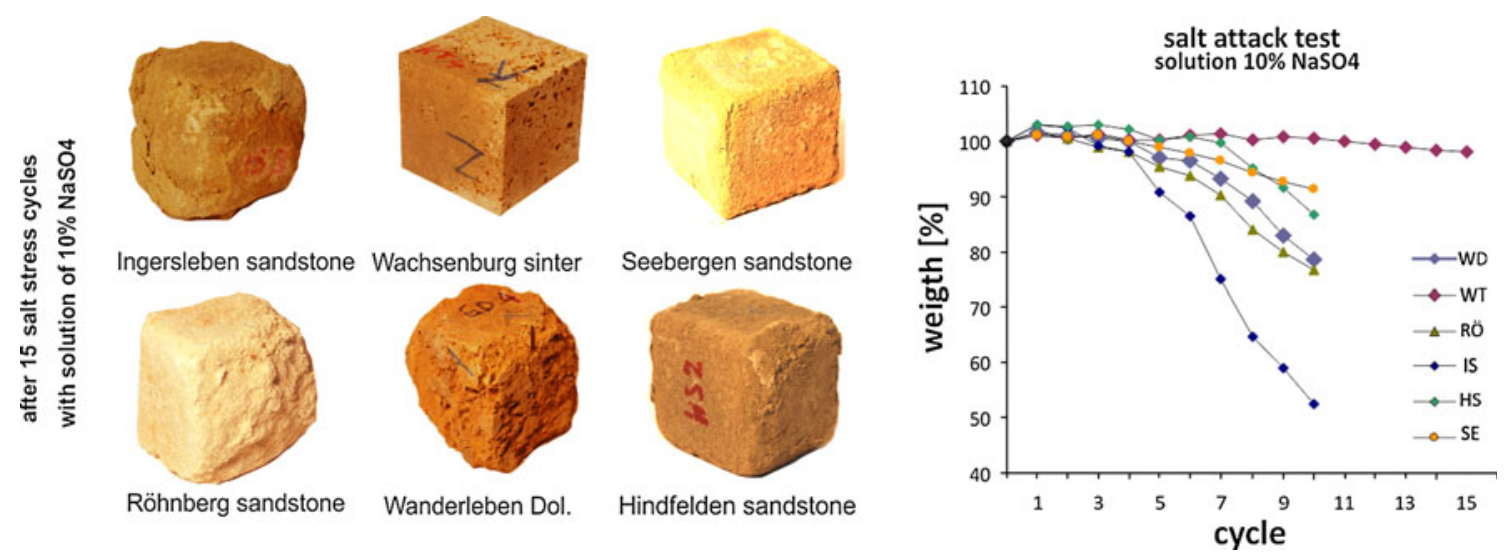

Fig. 19 Salt weathering test: damage phenomena of the samples on the left and diagram of the weight change with each cycle 
rocks were used for the construction of the three castles in the Drei Gleichen area. Eight different building stones were mined, six sandstones (Late Triassic) as well as two carbonates (Late Triassic and Quaternary).

The field observations as well as the laboratory experiments indicate that there are strong differences between the various rock types in respect to their suitability for construction. This is the result of their respective depositional environment and geological history, which lead to strong variations in the fabric and their petrophysical properties. The investigations have shown that the deterioration of the rocks was mainly controlled by physical weathering processes such as salt crystallisation and moisture expansion. In these processes water transport and retention properties of the rocks play an important role, which are also controlled by the rock fabric and the pore space properties.

Relationship between petrology and pore space properties

In general, the porosity of sandstone depends on its diagenesis, where the controlling factors are compaction, cementation or dissolution. However, the (primary) pore size distribution is controlled by the sorting of the sandstone (Füchtbauer 1988; Tucker 2001).

The porosity evolution of the six sandstones investigated in this study and their pore size distribution can be classified into mature and immature rocks. The maturity can be divided into compositional and textural sediments. Textural immature sediments are those with poor sorting and angular grains; mature sediments are those with moderate to good sorting and subrounded to rounded grains. The compositional maturity is characterised by the content of stable grains such as quartz in proportion to labile grains consisting of lithoclasts and feldspars (Pettijohn 1975; Folk 1974; Tucker 2001).

The Seebergen, Gleichenberg and Wachsenburg sandstones represent quartz-arenites to subarkoses (Fig. 11; Table 2) and are characterised by a pronounced textural and compositional maturity. However, the compaction and cementation leads to differences in the porosities. Whereas the Seebergen sandstone exhibits a clearly reduced primary porosity by compaction and quartz cementation, the Röhnberg sandstone shows a low compaction with accompanying point contacts between the grains. Moreover, the well sorting causes a narrow spaced maximum of capillary pores in the pore size distribution of the Seebergen and Gleichenberg sandstones (Fig. 16f; Table 2). The pore size distribution of the Röhnberg sandstone differs from the other two sandstones. In this case the presence of quartz enclosed by illite coatings also generates smaller pores. The Wachsenburg sandstone exhibits a higher content of feldspar and is poorly sorted. The low porosity was generated by compaction, which is evidenced by numerous pressure solution phenomena and syntaxial quartz growth fringes. Another diagenetic phase of calcite cementation further reduced the porosity. Although all three sandstones form the top of the Rhaetian Hills in the Drei Gleichen area, they show a very different porosity evolution with an accompanying different material behaviour (see explanation below).

The sandstones from Hindfelden and Ingersleben are litharenite in composition (Fig. 11) and originated in a fluvial environment. They are compositionally immature (Table 2); however, they are moderately to well sorted. In both sandstones, all quartz grains show overgrowths (Figs. 11d, 12b). Furthermore, alteration and partial replacement of feldspar and lithic clasts are accompanied by the formation of new clay minerals. The replacement increases the volume making up the interstitial matrix, which affects the homogeneity appreciably and gives rise to a greywacke-type of fabric (Tucker 2001). The clay does not retain its shape, but becomes squeezed between more rigid grains. Simultaneously, the porosity increases by the dissolution or replacement of unstable grains. Generally, the alteration from original stable grains or lithoclasts goes along with an increase of smaller pores between the newly generated networks of clay minerals. In the case of the Hindfelden sandstone, the volume of micropores is higher than in the sandstone of Ingersleben (Fig. 16c, d).

The porosity development in the two carbonates is due to their different origin in contrast to the sandstones, since delivery coincides with deposit area. Carbonates that develop in shallow water form metastable calcite during deposition and undergo phase transition to stable calcite or dolomite during diagenesis. During the process of diagenesis, grain size can either increase (sparitic growth) or decrease (micritisation), as well as the pore space can increase (solution) and decrease (cementation, compaction).

The porosity in the Wandersleben dolomite depends on its genesis and the fossil content, which influences the development of a primary or secondary porosity. The dolomite is generally altered by a secondary process from calcite to dolomite. Since dolomite has a higher density than calcite, vugs or cavities are common for dolomites and creates an increase in the porosity. In contrast, the porosity decreases when calcite is recrystallised and forms a sparitic calcite cement around the fossils. Moreover, when abundant fossils are present large-scale pore spaces are generated, whereas the micritic fabric does not allow the development of micropores. Therefore, the dolomite shows a unimodal pore size distribution with a large average pore size (Fig. 16a).

The porosity development of the Holocene non-compacted Wachsenburg sinter mainly depends on the calcified plant particles incorporated into the rock during its 

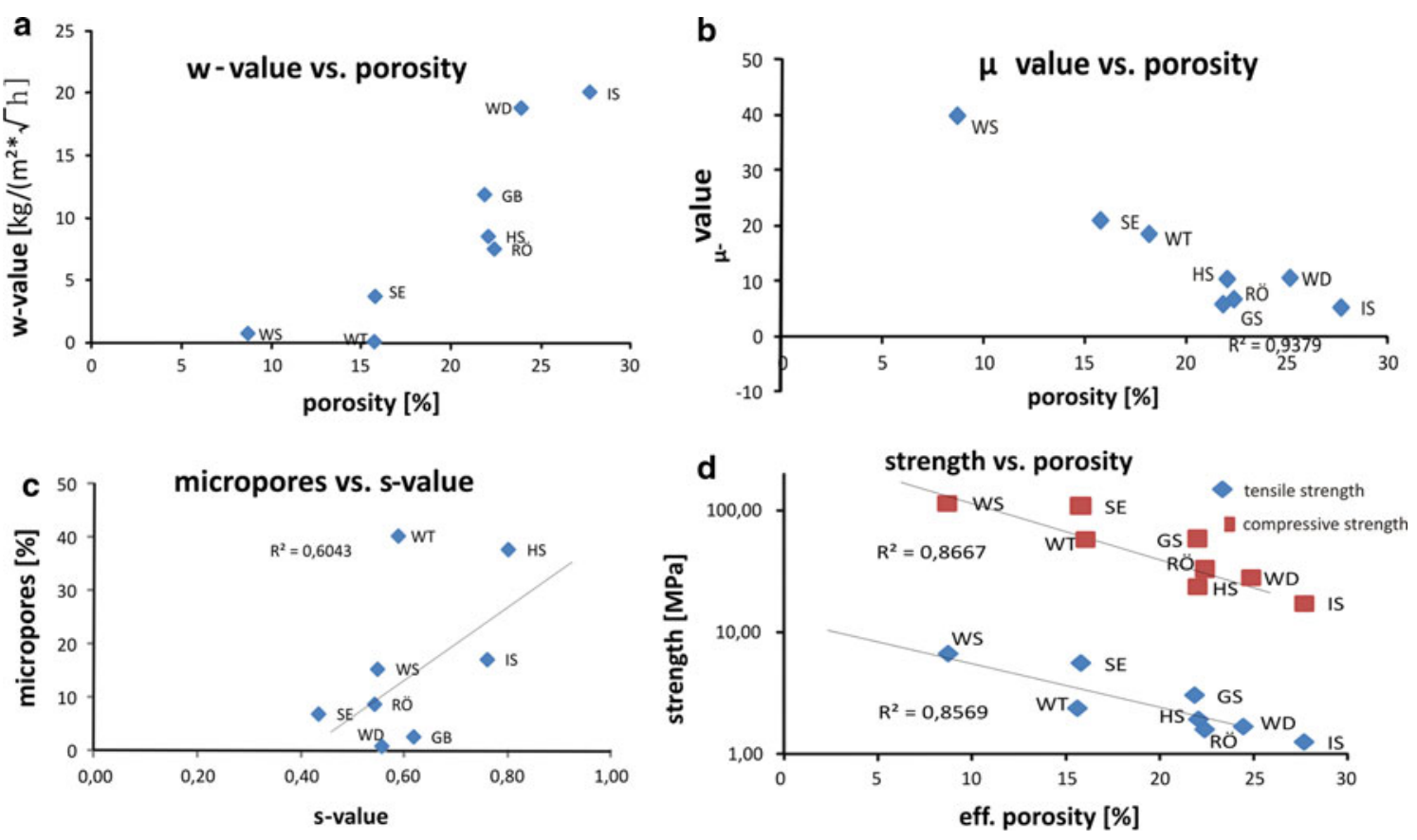

Fig. 20 Correlations of petrophysical properties. a $w$ value dependent on porosity, $\mathbf{b} \mu$ value dependent on porosity, $\mathbf{c}$ content of micropores dependent on $s$ value and $\mathbf{d}$ tensile and compressive strength dependent on porosity

formation. Since the plant particles show a size of up to several centimetres in length, the stones are characterised by a well-developed pore space network (Fig. 13b). The remaining material consists of micritic calcite, which does not allow for the development of many micropores.

Relationship between pore space, water balance and strength

The pore space and its properties significantly affects the weathering resistance of a natural building stone, since the pore space coevally rules the water balance (Fitzner 1988; Fitzner and Snethlage 1982; Putnis et al. 1995; Putnis and Mauthe 2000; Ruedrich et al. 2010a). Therefore, properties such as capillary water uptake, water vapour diffusion and saturation degree correlate in the present study with the porosities of the rocks. However, the pore size distribution and the network of single pore sizes among each other defines the intensity of the water uptake (Ruedrich and Siegesmund 2006; Siegesmund and Dürrast 2011) and at least the weathering resistance of sandstones (Fitzner and Snethlage 1982).

The ability of the rocks for capillary water uptake strongly depends on the porosity as well as on (the group of) pore size distributions. In general, the higher the water uptake, the higher is the porosity (Fig. 20a). The Wachsenburg sinter does not fit this trend. The large pores of the Wachsenburg sinter cannot connect, and thereby create a network between the few occurring capillary pores.
The Wachsenburg sandstone with a pore size distribution, belonging to group ii (Fig. 15) and showing a unimodal distribution with a maximum in capillary pores, exhibits a very low w value. A medium water uptake can be seen in the sample from groups iii (weak bimodal distribution; Hindfelden sandstone) and iv (weak unimodal distribution; Seebergen and Röhnberg sandstone) (Figs. 15, 16). The samples with the highest $\mathrm{w}$ values belong to group $\mathrm{i}$ : Wandersleben dolomite, Ingersleben sandstone and Gleichenberg sandstone (Figs. 15, 16). This suggests that not only the abundance of capillary pores is important for the intensity of capillary water uptake, but also the connection of capillary pores, which can be confirmed by the saturation degree (s value). The correlation between saturation degree and micropores as well as the sorption (max. weight increase) is nearly linear (Fig. 20c). The porosity correlates positively to the capillary water uptake (Fig. 20a). If the values deviate from this path, the samples not only show a high amount of macropores, but also a high content of micropores (Fig. 16). The observed interconnection between the $w$ value and the (fabric) texture is different. The sandstones with a well-pronounced bedding also show a distinct anisotropy of the $w$ value. The reason for this anisotropy may be the grain shape as well as the orientation of the grains. Parallel to the bedding, the pore space or the network of pores is well developed. Water can easily pass through the rock, and thus the pores build an interconnected network. The anisotropy of the two carbonates is not that well pronounced. In the case of the Wandersleben 
dolomite this can be explained by the small interstitial fossils, which are not aligned parallel to the bedding. The $w$ value of the Wachsenburg sinter is very small, so that any conclusion concerning the anisotropy is difficult to make.

The water transport via water vapour diffusion also depends on the porosity, but here the higher the $\mu$ value, the lower is the porosity (Fig. 20b). This means that sandstones with a large medium pore radii show a high $w$ value and a low $\mu$ value. The hygroscopic water uptake depends significantly on the amount of micropores, because the hygroscopic water absorption takes place in smaller pores (Peschel 1983; Klopfer 1985; Siegesmund and Dürrast 2011). Therefore, samples with a high micropore content also show a very high increase in weight at higher humidities. However, some samples do not follow this trend. For example, although the sandstone Seebergen exhibits more or less the same amount of micropores, the hygroscopic water uptake is clearly lower than the Röhnberg sandstone. Most likely the micropores of the Seebergen sandstone are not very well interconnected. In general, the weight increase does not depend on the porosity. Highly porous sandstones, such as the Ingersleben and Gleichenberg sandstone and the low porous Wachsenburg and Seebergen sandstones, can show medium weight increases.

Along with the water balance, the strength in stones is important for the resistance against weathering, because when the strength of a rock is exceeded the fabric begins to disintegrate. The measured tensile and compressive strength in the sandstones depend on these three factors: the porosity (medium pore radii), the grain contact and cementation. Sandstones with low porosity show mainly quartz cementation, concave-convex to sutured grain contacts and they exhibit a high tensile and compressive strength. This type of rock is represented by the sandstones of Seebergen and the Wachsenburg. They show sutured grain contacts as well as quartz cementation and partially calcite cement, which stabilizes the framework and results in a high strength. In contrast, the sandstones from Hindfelden and Ingersleben are characterised by a highly ductile clayey matrix or lithoclasts that do not allow the formation of stable grains to be built for generating a strong granular grain structure. Moreover, the Rät sandstones from Röhnberg and Gleichenberg show a low strength, caused by its high porosity and the predominant point contact. The observed decrease of strength at the water-saturated state was already mentioned by Hirschwald (1908) and is called "softening". According to Morales et al. 2007 or Siedel (2010), this effect can reach a decrease of 50\% in sandstones. In the present study, the Hindfelden and Ingersleben sandstone nearly reach a decrease of this amount. Seebergen and Semionotus sandstones only show a slight decrease through water saturation.
The strength of the two carbonates is, besides the amount of porosity and micritic/sparitic areas, controlled by the heterogeneous distribution of large pores, which is also confirmed by the high standard deviation. Measured samples with an inappropriate distribution of large, elongated pores cannot develop a stable network of calcite, which is why they exhibit a very low strength. In contrast, some areas consisting of smaller pores and a micritic fabric show very high strength properties.

\section{Weathering properties}

The investigation of weathering behaviour on-site and in the laboratory show that many occurring decay phenomena can be traced back to moisture expansion as well as salt crystallisation in the pore space. Moreover, the intensity and shape of deterioration depends on different rock parameters.

Sandstones with a high porosity, high content of micropores and altered lithoclasts $(>20 \%)$, like the litharenites from Hindfelden and Ingersleben, show very high values for moisture expansion, which is confirmed by the studies of Ruedrich et al. (2010a). The Hindfelden sandstone reaches the maximum length change for sandstones during moisturisation with a value of $\sim 5 \mathrm{~mm} / \mathrm{m}$ (Schuh 1987; Snethlage and Wendler 1996). In contrast, the quartz-arenites and subarkoses with high quartz contents show low porosities and low contents of micropores as well as low moisture expansion values. Furthermore, sandstones with distinctly pronounced bedding, such as Hindfelden, Ingersleben and Gleichenberg sandstones, show a clear anisotropy.

The results of the salt attack tests agree with other studies on German sandstones (Snethlage and Wendler 1996, Fitzner and Snethlage 1982, Rossi-Manaresi and Tucci 1991, Ruedrich et al. 2005, Ruedrich and Siegesmund 2006), where samples with a high amount of smaller capillary pores and micropores are highly sensitive to salt attack. According to Snethlage and Wendler (1996), the pore space properties, such as porosity and pore size distribution, control the solution transportation and restore behaviour, and in consequence also the salt distribution and enrichment in the rock. Thus, a link between the salt attack resistance and the groups of pore size distributions is observable. Rocks belonging to group i and iii (Figs. 16, 17) have high amount of micropores and exhibit low resistance during salt attack.

According to Ruedrich and Siegesmund (2007), the different deterioration phenomena during salt attack tests can be traced back to the pore space properties. Sandstones, showing a slow drying rate, exhibit scaling as the main phenomenon. In contrast, sandstones with a high drying velocity show sanding as the prevalent deterioration 
phenomenon. Moreover, the strength of the rocks seems to influence the sensitivity to salt attack. Rocks, showing a low strength, such as Hindfelden and Ingersleben, are less resistant than rocks with a high strength, like the Wachsenburg sandstone or Wachsenburg sinter. This was also observed by Ruedrich et al. 2005 .

\section{Conclusions-construction suitability}

The investigation of the material behaviour and the deterioration at the residential building ruins allows an evaluation to be made concerning construction suitability and possible material replacement. Without considering the present day mining situation in the Drei Gleichen area, any possible replacement of deteriorated stones at the building may not be done, if no suitable material can be found in the region. At present, the mining of natural building stones depends on the availability of the material, but less so on the means of transporting the stones. However, luctrative mining is limited by the material behaviour of the rocks.

- In the natural environment, only the Wachsenburg sinter shows a marginal deterioration, which was also verified by the laboratory tests. Besides a low thermal coefficient, the rock shows a minor moisture expansion and a high resistance against salt loading. This behaviour can probably be traced back to its pore space properties, which allows just minor water uptake or water storage in the pore spaces. The other carbonate behaves differently. The Wandersleben dolomite deterioration is characterised by different shapes and intensities. In laboratory tests, the rock exhibits a distinct moisture expansion similar to the sandstones, which also results in decay-like flaking, scaling and salt efflorescence. Here the pore size distribution promotes the capillary water uptake, whereas hygroscopic water uptake is marginal. Simultaneously, the minor strength also allows a slight deterioration through salt loading.

- Even though the sandstones from Seebergen, Röhnberg and Gleichenberg are exposed relatively close and show the same stratigraphical age, they all exhibit a totally different material behaviour. The Seebergen sandstone mainly shows a weak deterioration in the natural environment and in laboratory tests. This is due to its mineralogical composition that results in a high strength. Furthermore, the pore space properties promote a low water uptake. In contrast, under outdoor conditions, the Röhnberg sandstone shows intensive deterioration in the shape of flaking and sanding. This is due to the grain boundary configuration, e.g. the rock exhibits grain point contacts. The crystallisation of salt in the pore space of this weakly cemented sandstone can easily exceed the strength of the rock. The Gleichenberg sandstone mainly shows deterioration in the form of relief, which is due to its well-developed bedding. In this sandstone, the pore space distribution shows a high water uptake, whereas the grain contact that results in a high porosity causes the rock to have a low strength. All Rät sandstones show a low hygric swelling and also small thermal expansions coefficients, which are the results of the rock's mineralogical composition. Only salt loading causes a difference. Whereas the Gleichenberg and Röhnberg sandstones show a distinct deterioration due to salt (also in the field), the sandstone from Seebergen only exhibits a slight disintegration. Therefore, the Seebergen sandstone can be considered a suitable dimension or replacement stone.

- Next to the Seebergen sandstone, one of the most weathering resistant stones of the Drei Gleichen area is the Wachsenburg sandstone that only occurs as minor exposures. In the field as well as in the laboratory, this stone shows just a weak deterioration, which can be explained by its porosity evolution and the low water uptake and high strength. The water uptake and the strength properties prove that this sandstone meets the structural and engineering specifications for use as a dimension stone. However, the deposit is only locally exposed in a small area below the Wachsenburg, and thus replacing the deteriorated stones with fresh ones is near to impossible.

- The most susceptible stones with regard to weathering in the area are the altered lithoclast-rich sandstones from Hindfelden and Ingersleben. Because of their low strength the stones are easily workable, but also show a low resistance to weathering. The presence of altered lithoclasts as well as an inappropriate pore size distribution results in low strength properties and a high water uptake. Sandstones showing a better water balance but similar strength properties (e.g. lower content of altered lithoclasts) would probably be more suitable as a replacement stone.

Acknowledgments We would like to thank the Deutsche Bundesstiftung Umwelt for supporting the Drei Gleichen project and the long-term PhD fellowship for H. Stück (AZ 20008/997). Furthermore, gratitude also goes to A. Török for his very helpful comments on an earlier version of this paper and to Chr. Gross for editing the English.

Open Access This article is distributed under the terms of the Creative Commons Attribution Noncommercial License which permits any noncommercial use, distribution, and reproduction in any medium, provided the original author(s) and source are credited. 


\section{References}

Beutler G (1980) Beitrag zur Stratigraphie des Unteren und Mittleren Keupers. Z Geol Wiss 8(8):1001-1018

Beutler G, Schubert J (1987) Fazielle Entwicklung des Mittleren Lettenkeupers im Thüringer Becken. Z Geol Wiss 15:475-484

Beutler G, Schubert J, Siegesmund S (2010) Geologie und Landschaftsentwicklung des Drei-Gleichen-Gebietes. In: Siegesmund S, Hoppert M (eds) Die Drei Gleichen-Naturdenkmäler und Naturraum. Edition, Leipzig, pp 48-62

Deutsche Stratigraphische Kommision, Menning M, Hendrich A (eds) (2002) Stratigraphische Tabelle von Deutschland 2002. ISBN 3-00-010197-7

DIN 52102 (1988) Bestimmung von Dichte, Trockenrohdichte, Dichtigkeitsgrad und Gesamtporosität. Berlin: Beuth

DIN 52103 (1988) Bestimmung von Wasseraufnahme und Sättigungswert. 3 S., Berlin: Beuth

DIN 22024 (1989) Bestimmung der Spaltzugfestigkeit von Festgesteinen. Berlin: Beuth

DIN 52615(1987) Bestimmung der Wasserdampfdurchlässigkeit von Bau- und Dämmstoffen. 5 S., Berlin: Beuth

Dunham RJ (1962) Classification of carbonate rocks according to depositional texture. In: Ham WE (ed) Classification of carbonate rocks-a symposium; AAPG Memoirs 1, 108-121, Tulsa

Fitzner B (1988) Untersuchung der Zusammenhänge zwischen dem Hohlraumgefüge von Natursteinen und physikalischen Verwitterungsvorgängen. Mitt. Ing.-u.Hydrogeologie, 29, Aachen

Fitzner B, Snethlage R (1982) Einfluß der Porenradienverteilung auf das Verwitterungsverhalten ausgewählter Sandsteine. Bautenschutz und Bausanierung. Nr 3:97-103

Folk RL (1974) Petrology of sedimentary rocks. Hemphill Publishing, Austin

Füchtbauer H (1988) Sedimente und Sedimentgesteine.- 4. Auflage. Stuttgart, Schweizerbart, p 1141

Hirschwald J (1908) Die Prüfung der natürlichen Bausteine auf ihre Wetterbeständigkeit. Z. prakt. Geologie 16:257-264

Hobohm C (2010) Sagen und Märchen aus dem Drei Gleichen Gebiet-Eine literarische Wanderung. In: Siegesmund S, Hoppert M (eds) Die Drei Gleichen-Naturdenkmäler und Naturraum. Edition, Leipzig, pp 10-45

Hopf U (2010) Geschichte und Baugeschichte der Drei Burgen. In: Siegesmund S, Hoppert M (eds) Die Drei Gleichen-Naturdenkmäler und Naturraum. Edition, Leipzig, pp 76-101

Klopfer H (1985) Feuchte. In: LUTZ et al (eds) Lehrbuch der Bauphysik. Teubner Verlag, Stuttgart, pp 265-434

McBride EF (1963) A classification of common sandstones. J Sed Petrol 33(3):664-669

Morales M, Jahns E, Ruedrich J, Oyhantçabal P, Siegesmund S (2007) The impact of partial water saturation in rock strength: an experimental study on sandstones. Z. dt. Ges Geowiss 158(4): 869-882

Paul J, Wemmer K, Ahrend H (2008) Provenance of Triassic siliciclastic sediments in Central Europe. Z. dt. geol. Ges. 159: 641-650

Peschel A (1983) Natursteine.-2. Auflage, 448 S.; VEB Deutscher Verlag für Grundstoffindustrie, S. 447, Leipzig

Pettijohn FJ (1975) Sedimentary rocks. Harpers u. Brothers, New York

Puff P (1994) Thüringen-Geologische Übersicht 1:400,000. Gotha, Perthes

Putnis A, Mauthe G (2000) The effect of pore size on cementation in porous rocks. Geofluids 1:37-41

Putnis A, Prieto M, Fernandez-Diaz L (1995) Supersaturation and crystallisation in porous media. Geol Mag 132:1-13
Rossi-Manaresi R, Tucci A (1991) Pore structure and the disruptive or cementing effect of salt crystallization in various types of stone. Stud Conserv 36:53-58

Ruedrich J, Siegesmund S (2006) Salt and ice crystallisation in porous sandstones. Environ Geol 52(2):225-249

Ruedrich J, Siegesmund S (2007) Salt induced weathering: an experimental approach. Environ Geol 52:225-249

Ruedrich J, Kirchner D, Seidel M, Siegesmund S (2005) Deterioration of natural building stones induced by salt and ice crystallisation in the pore space as well as hygric expansion processes. In: Siegesmund S, Auras M, Ruedrich J, Snethlage R (eds) Geowissenschaften und Denkmalpfleg. Zeitschrift Deutsche Geologische Gesellschaft, 156/1, 59-73

Ruedrich J, Bartelsen T, Dohrmann R, Siegesmund S (2010a) Building sandstone integrity affected by the process of hygric expansion. Environ Earth Sci. doi:10.1007/s12665-010-0767-0

Ruedrich J, Kirchner D, Siegesmund S (2010b) Physical weathering of building stones induced by freeze-thaw action: a laboratory long-term study. Environ Earth Sci, Special Issue

Schubert J, Klug W, Hopf U, Siegesmund S (2010) Geologische, botanische und burgengeschichtliche Exkursionen. In: Siegesmund S, Hoppert M (eds) Die Drei Gleichen. Naturdenkmäler und Naturraum, Edition Leipzig, pp 312-351

Schuh H (1987) Physikalische Eigenschaften von Sandsteinen und ihren verwitterten Oberflächen. Münchner Geowiss. Abh., 6: S. 66; Enke Verlag, Stuttgart

Seidel G (2003) Geologie von Thüringen, Schweizerbart'sche Verlagsbuchhandlung, Stuttgart, 2. Aufl

Siedel H (2010) Historic building stones and flooding: changes of physical properties due to water saturation. J Perform Constr Facil 24(5). doi:10.1061/(ASCE)CF.1943-5509.0000066

Siedel H, Siegesmund S, Sterflinger K (2011). Characterisation of stone deterioration on buildings, 2011. In: Siegesmund S, Snethlage R (eds) Stone in architecture. pp 347-410. doi: 10.1007/B78-3-642-14475-2_6 Springer-Verlag, Berlin

Siegesmund S, Dürrast H (2011). Mechanical and physical properties of rocks, 2011. In: Siegesmund S, Snethlage R (eds) Stone in architecture. pp 97-225. doi: 10.1007/ß78-3-642-14475-2_3 Springer-Verlag, Berlin

Siegesmund S, Snethlage R (2011). Stone in architecture. Springer, 4th ed. doi:10.1007/978-3-642-14475-2, Sprinter-Verlag, Berlin, $1-552 \mathrm{pp}$

Siegesmund S, Grimm WD, Dürrast H, Rüdrich J (2010). Limestones in architecture: the German view. In: Smith B, Gomez-Heras M, Viles H, Cassar $\mathbf{J}$ (eds) Limestone in the built environment: present day challenges to preserve the past. Geol Soc Spec Pub London 331:37-59

Snethlage R, Wendler E (1996) Moisture cycles and sandstone degradation. In: Baer NS, Snethlage R (eds) Saving our architectural heritage, the conservation of historic stone structures. Elsevier, Chichester, pp 7-24

Tröger WE (1967) Optische Bestimmung der gesteinsbildenden Minerale, Teil 2: textband. Schweizerbart'sche Verlagsbuchhandlung, Stuttgart, x. Auflage

Tucker M (2001) Sedimentary petrology. Blackwell Science Inc, Oxford, p Revised 272

van Brakel J, Modry S, Svata M (1981) Mercury porosimetry: state of the art. Powder Technol 29: S. 1-12

Weiss T, Siegesmund S, Kirchner D, Sippel J (2004) Insolation weathering and hygric dilatation: two competitive factors in stone degradation. Environ Geol, Special Issue: Stone Decay Hazards, 46/3-4, S. 402-413

Wurster P (1964) Geologie des Schilfsandsteins, Heft 33, S. 140. Mitteilungen des GeologischenStaatsinstitutes, Hamburg 